WIN-48

Metallurgy-Raw Materials

M-3679 - 18th Edition

$-1=$

\title{
PRECIPITATION OF MOLYBDENUM FROM ION EXCHANGE FEEDS BY NEUTRALIZATION IN THE PRESENCE OF TRON
}

\author{
By
}

Paul J. Magno

November 15,1956

$\frac{\text { Taul \&. Yoagero }}{\text { Pati J. Magro }}$

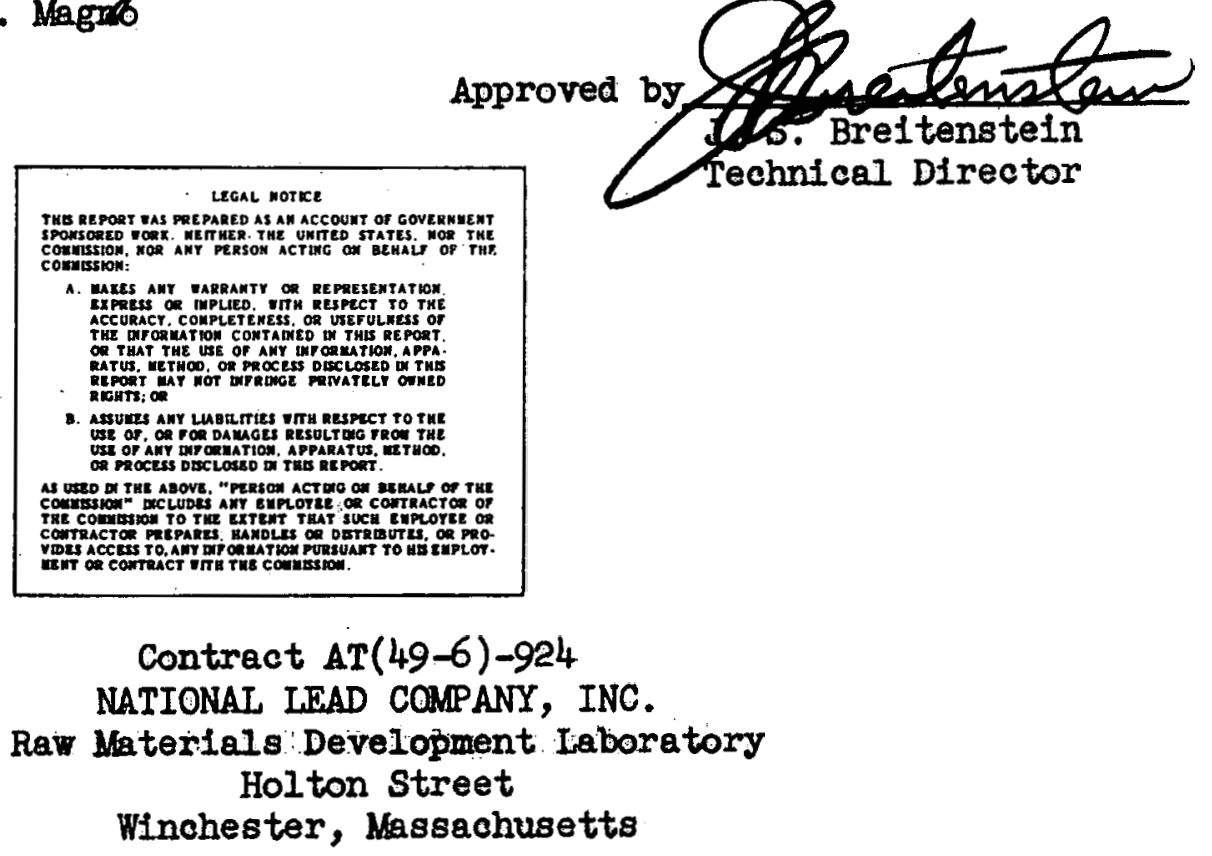




\section{DISCLAIMER}

This report was prepared as an account of work sponsored by an agency of the United States Government. Neither the United States Government nor any agency Thereof, nor any of their employees, makes any warranty, express or implied, or assumes any legal liability or responsibility for the accuracy, completeness, or usefulness of any information, apparatus, product, or process disclosed, or represents that its use would not infringe privately owned rights. Reference herein to any specific commercial product, process, or service by trade name, trademark, manufacturer, or otherwise does not necessarily constitute or imply its endorsement, recommendation, or favoring by the United States Government or any agency thereof. The views and opinions of authors expressed herein do not necessarily state or reflect those of the United States Government or any agency thereof. 


\section{DISCLAIMER}

Portions of this document may be illegible in electronic image products. Images are produced from the best available original document. 
WIN -48

\section{ABSTRACT}

The removal of molybdenum from acld leach liquors by neutralization in the presence of iron has been evaluated as a method of decreasing the concentration of molybdenum to a tolerable level in ion exchange feeds. Such variables as acid concentration, iron to molybdenum ratio, temperature, and concentration of silicate and aluminum in the leach liquor were examined in order to develop the optimum conditions for the precipitation of molybdenum.

The precipitation procedure was tested on leach 11quors from Ambrosia Lake District ore and from several lignite ores. Leaching tests made on lignite ores indicate that Iron and molybdenum can be precipitated during the leaching by suitable control of the acidity. 
TABIE OF CONTENTS

\section{Page}

INTRODUCTION

SUMMARY AND CONCLUSIONS

APPARATUS AND REAGENTS

VARIABLES IN THE PRECIPITATION OF MOLYBDENUM AND IRON 8

Acid Concentration

8

Iron to Molybdenum Ratlo

Temperature

Silicate Concentration

Aluminum Concentration

COMPOSITION OF THE PRECIPITATE 12

RECOVERY OF COPRECIPITATED URANIUM

REMOVAL OF MOLYBDENUM FROM AMRROSIA IAKE IEACH IIQUORS

Molybdenum Precipitation and Ion Exchange - Batch Tests 15 Cyclic Leaching and Molybdenum Precipitation 16

REMOVAL OF MOLYBDENOM FROM LIGNITE LEACH LIQUORS 18

Neutralization of Leach Liquors from Several Lignites 18

Molybdenum Removal and Ion Exchange 19 Bryco Hilltop Sample 185-16 19

Peter Kiewit Sample 185-18 21

Effect of Recycling Repulp Solution 23

Predipitation of Molybdenum During Leaching 24

LITERATURE CITED

TABLES $26-38$ 
WIN -48

$-4-$

\section{INTRQDUCTION}

Molybdate is known $(1,2,3)$ to be a serious interference in the recovery of uranium from acid leach llquors by ion exchange. Molybdenum is strongly adsorbed by anion exchange resins along with the uranium during the loading cycle, but is not removed from the resin in the normal elution procedure for uranium. This behavior results in an accumulation of molybdenum on the resin which leads to a decrease in the adsorption rate of uranium and ultimately to a decrease in the resin capacity.

Formerly, a periodic regeneration of the resin with 6 per cent sodium hydroxide was used to remove the molybdenum (2); more recently, it has been shown that a solution containing 0.5 per cent sodium hydroxide and 0.1 molar chloride or nitrate will effectively elute the molybdenum from the resin (3). Nevertheless, because of the effect of molybdenum on the rate of adsorption of uranium, a more satisfactory solution to the problem would be the removal of the molybdenum from the liquor before ion exchange.

Since it is known that at the Union Miniere du Haut-Katanga in the Belgian Congo the neutralization of acld leach liquors to a $\mathrm{pH}$ of 2.8 resulted in the precipitation of ferric Iron and molybdenum, an investigation of this method of molybdenum removal was inftiated. The purpose of this investigation was to study some of the factors which effect the precipitation of molybdenum with ferric 1ron and to apply the information toward the development of methods for the removal of molybdenum from acid leach liquors prior to the recovery of uranium by ion exchange. 
The removal of molybdenum from acid liquors by neutralization in the presence of ferric iron is governed by a number of interrelated variables. As the acidity of a solution containing molybdenum and iron is decreased, increasing amounts of molybdenum and Iron are precipitated. If the molar ratio of iron to molybdenum is less than 8 to 1 , some molybdenum remains in solution even at $\mathrm{pH} 3.6$. However, very excellent precipitation can be made at somewhat lower molar ratios. Also, as the concentration of iron is increased, quantitative removal of molybdenum is achieved at lower $\mathrm{pH}$ 's. Increasing the temperature of the solution results in more complete removal of molybdenum and iron at any particular acid and iron concentration.

The removal of molybdenum by this technique is more difficult if the molybdenum has been complexed in solution by silicate to form molybdosilicic aeld or by aluminum to form some type of aluminum-molybdenum complex. Each of these obstacles can be greatly diminished by increasing the temperature at which the precipitation is made. Also, a high concentration of aluminum increases the amount of calcium carbonate required for neutralization and tends to retard the precipitation of the iron and molybdenum.

No definite composition oan be assigned to the iron-molybdenum precipitate since its composition varies with acidity and the Iron to molybdenum ratio.

Some uranium is removed from solution during the precipitation of Iron and molybdenum. The amount of uranium coprecipitated increases with the Iron content of the solution and the $\mathrm{pH}$ at which the precipitation is made, but is relatively independent of the uranium concentration. Increasing the temperature at which the precipitation is made decreases the amount of uranium removed from solution. The uranium in the iron-molybdenum precipitate can be almost completely recovered by an acid repulp of the precipitate with only small amounts of iron and molybdenum being redissolved at the proper conditions of acidity. 
WIN -48

Cyclic tests involving leaching, precipitation of molybdenum, and repulp of the precipitate in the succeeding leach pulp subsequent to the strong acid leach were made. During a test of seven such cycles on leach liquor from a sample of ore from the Ambrosia Lake District, the ferric iron concentration increased from 0.5 to 2.1 grams per liter and the molybdemum concentration increased from 0.047 to 0.083 grams per 1iter. The precipitate at the end of the seventh cycle contained onl 0.2 per cent of the total amount of uranium in the ore.

The molybdenum concentration of leach liquers from Edgemont, Farmington, and Northgate lignite was reduced to a level of 1 to $2 \mathrm{ppm}$ by the preaipitation technique. However, in leach liquors prepared from Bryco and Peter Kiewit lignite, the molybdenum concentration was redueed only to 10 to 20 ppm. A series of cyclic tests made on leach liquor prepared from Bryco Iignite Indicated that there is no iron and molybdenum buildup in the liquor, but a very substantial buildup of the aluidnum concentration takes place. The amount of caloium carbonate required to neutralize the leach Iiquors increased from 380 to 650 Ibs per ton of ash over four eycles, and therefore this type of process would not be practical for this ore because of excessive reagent costs.

The possibility of controlling the amounts of molybdenum present in acid leach filtrates through control of the leaching copditions was studied. Test work conducted on several Iignite ore samples Indicated that leach liquors relatively free of molybdenum can be produced through the use of a relatively high $\mathrm{pH}$ leach. A two-stage leaching procedure with close control of acidity and temperature at each stage is suggested as the best method of producing a Low molybdenum pregnant solution from lignites. 
WIN -48

$-7-$

\section{APPARATUS AND REAGENTS}

The following reagents were used in preparing the solutions used for the test work presented in this report.

Ammoniun Molybdate - Baker \& Adamson Reagent Grade Uranyl Sulfate - Fisher Solentific Company

Ferric Sulfate (Crystals) - Fisher Scientific Company Aluminum Sulfate - Baker \& Adamson Reagent Grade Sodium Metasillcate - Baker \& Adamson Reagent Grade

All solutions were prepared using distilled water received from the Belmont Springs Water Company. Solutions of ammonium molybdate were stored in polyethylene bottles.

Measurements of $\mathrm{pH}$ were ude using a battery operated Beckman Model $\mathrm{N}$ pH meter.

Precipitations were made in the following manner: calcium carbonate was added to the solution until precipitation began; this resulted in a drop in the $\mathrm{pH}$; the final $\mathrm{pH}$ was then adjusted by addition of calcium carbonate until the pH of the solution remained constant for 10 to 15 minutes at the desired value.

For the purposes of this report, any precipitation which leaves only 0.001 gram of molybdenum per liter or less remaining in solution will be referred to as "a complete precipitation of molybdenum." 
VARIABLES IN THE PRECIPITATION OF IRON AND MOLYBDENUM

\section{Acid Concentration}

In order to test the effect of acid concentration or $\mathrm{pH}$ on the precipitation of molybdenum by ferric iron, a solution containing $0.05 \mathrm{M}$ ferric iron and $0.025 \mathrm{M}$ molybdenum was prepared. The $\mathrm{pH}$ of this solution was raised from 1.0 to 9.0 by the addition of lime. Samples were taken periodically over the entire pH range, filtered and analyzed for iron and molybdenum. Results of this test are shown in Table I.* These results show that increasing amounts of molybdenum and iron are precipitated as the $\mathrm{pH}$ is raised up to a value of 3.8 ; at this point all the iron is precipltated, but some molybdenum remains in solution. Maximum precipitation of the molybdenum is obtained in the $\mathrm{pH}$ range of 3.4 to 3.8 . Raising the $\mathrm{pH}$ above this level resulted in some of the precipitated molybdenum being redissolved.

\section{Iron to Molybdenum Ratio}

When the $\mathrm{pH}$ of a solution containing $0.05 \mathrm{M}$ ferric iron and $0.025 \mathrm{M}$ molybdenum was raised to 3.4 to $3 . \overline{8}$ about 99 per cent of the molybdenum was precipitated. In order to determine what molar ratio of ferric iron to molybdenum must be present in solution in order to effect complete precipitation of the molybdenum, precipitations were made at pH 3.6 from solutions containing ferric iron and molybdenum in various ratios. Results of these tests are presented below in Table II.

Table II. The Effect of the Molar Ratio of Iron to

Molybdenum on the Precipitation of Molybdenum

$\frac{\text { Molar Ratio, }}{\text { Fe/Mo }}$

$\begin{array}{lll}1 / 4 & 1.40 & 9.60 \\ 1 / 2 & 1.40 & 4.80 \\ 1 / 1 & 1.40 & 2.40 \\ 2 / 1 & 1.40 & 1.20 \\ 4 / 1 & 1.40 & 0.60 \\ 8 / 1 & 1.40 & 0.30 \\ 16 / 1 & 1.40 & 0.15\end{array}$

Grams/Liter

$\underline{\mathrm{Fe}^{+++}} \stackrel{\text { Mo }}{ }$
Filtrate Assay

Head Solution

Grams/Liter

Fe $\underline{\text { Ho }}$

$0.23 \quad 2.54$

0.0150 .06

$0.008 \quad 0.02$

$0.005 \quad 0.009$

0.0050 .002

0.0030 .001

$0.004 \quad 0.001$

* The large tables are presented at the end of the report. 
These results show that an $8 / 1$ molar ratio of ferric iron to molybdenum is sufficient to effect complete precipitation of the molybdenum at $\mathrm{pH} 3.6$. However, very excellent precipitation can be made at somewhat lower ratios of iron to molybdenum. Ninety-nine per cent of the molybdenum was precipitated from a solution which contained an equimolar ratio of iron and molybdenum.

In order to study the effect of Iron concentration on the $\mathrm{pH}$ at which the precipitation of molybdenum occurs, a series of tests were made on solutions containing 1.0 gram Mo per liter and from 2.0 to 20 grams of $\mathrm{Fe}^{+++}$per liter. Precipitations were made in these solutions at $\mathrm{pH}$ values of $2.4,2.6,2.8$, $3.0,3.2,3.4$, and 3.6 by the addition of calcium carbonate to adjust the $\mathrm{pH}$. Data from these tests are presented in Table III. It can be seen that as the concentration of iron in solution increases, the $\mathrm{pH}$ of complete molybdenum precipitation decreases. However, this effect is not too marked since a tenfold increase in Iron concentration from 2.0 to 20 grams per liter resulted in a decrease in the $\mathrm{pH}$ required for complete precipitation from 3.6 to 3.0 .

\section{Temperature}

In order to test the effect of temperature on the precipitation of molybdenum along with iron as the $\mathrm{pH}$ of an acid leach liquor is increased, a series of tests were made on solutions containing 1.0 gram Mo per liter and 5.0 grams $\mathrm{Fe}^{+++}$per liter. Precipitations from these solutions were made at a number of $\mathrm{pH}$ values at $25,50,75$ and $100^{\circ} \mathrm{C}$. The results of these tests are presented in Table IV. A comparison of the results indicates that as the temperature increases, the $\mathrm{pH}$ at which complete molybdenum precipitation takes place decreases. It also appears that increasing the temperature causes more efficient precipitation of the molybdenum with iron.

\section{Silicate Concentration}

During the preliminary test work with iron and molybdenum solutions, considerable interferenoe was encountered in precipitating the molybdenum because of the presence of dissolved sillcate in the de-ionized water. It is well known that molybdenum and silicate combine in solution to form molybdosilloic acid. To evaluate the effect of the presenoe of silicate on the precipitation of molybdenum, a number of tests were performed. A solution containing 1.0 gram $\mathrm{SiO}_{2}$ per liter as silicate, 1.0 gram Mo per liter, and 5.0 grams $\mathrm{Fe}^{+++}$per liter was prepared by mixing the ferric iron and molybdenum prior to the addition of the silicate. From 
this solution, all of the molybdenum was precipitated at a $\mathrm{pH}$ of 3.5. If, however, the solution was prepared by mixing the silicate and molybdenum, acidifying, and then adding the ferric iron, precipltation at a pH of 3.5 showed only 48 per cent of the molybdenum was removed. This would indicate that some of the molybdenum was complexed as molybdosilicic acid.

To test the effect of temperature on the molybdosilicic acid complex, a solution was prepared by mixing the molybdenum and silicate, acidifying, and adding ferric iron. Precipitations were made from this solution at ambient temperature, 50, 75 and $100^{\circ} \mathrm{C}$ by adjusting the $\mathrm{pH}$ to a value at which complete preclpitation of the molybdemum could be expected. Results of these tests are presented below in Table V.

Table V. Effect of Temperature on Precipitation of Molybdenum Complexed as Molybdosilicic Acid

Head Solution Assay: $\mathrm{SiO}_{2}, 1.0 \mathrm{~g} / \mathrm{I} ; \mathrm{MO}, 1.0 \mathrm{~g} / \mathrm{I} ; \mathrm{Fe}^{+++}=5.0 \mathrm{~g} / \mathrm{l}$.

\begin{tabular}{|c|c|c|c|c|c|}
\hline \multirow[b]{2}{*}{$T^{\circ} \mathrm{C}$} & \multicolumn{3}{|c|}{$\frac{\text { Filtrate Assay }}{\text { Grams/Liter }}$} & \multicolumn{2}{|c|}{ E Precipitated } \\
\hline & $\mathrm{pH}$ & $\mathrm{Fe}^{+++}$ & $\overline{\mathbf{M O}}$ & $\mathrm{Fe}^{++t}$ & Mo \\
\hline $\begin{array}{l}\text { Amb } \\
50 \\
75 \\
100\end{array}$ & $\begin{array}{l}3.7 \\
3.1 \\
3.0 \\
2.7\end{array}$ & $\begin{array}{l}0.001 \\
0.010 \\
0.023 \\
0.008\end{array}$ & $\begin{array}{l}0.52 \\
0.36 \\
0.16 \\
0.004\end{array}$ & $\begin{array}{l}99.9 \\
99.8 \\
99.5 \\
99.9\end{array}$ & $\begin{array}{l}48.0 \\
64.0 \\
84.0 \\
99.6\end{array}$ \\
\hline
\end{tabular}

These tests indicate that heating of the solution breaks down the complex ion and alds in the preclpitation of molybdenum.

\section{Aluminum Concentration}

During the test work done on the application of this procedure for removing molybdenum from lignite leach liquors, it was found that the presence of substantial amounts of aluminum hindered the preoipitation of molybdenum and iron. Therefore, in order to test this effeot in pure solutions, a series of precipitations were made at $\mathrm{pH}$ values of $3.5,3.8$, and 4.1 from solutions containing 1.0 gram Mo per liter, 5.0 grams Fe per liter and various amounts of aluminum. The amounts of calclum carbonate used for precipitation were measured. The data are reported in Table VI. 
These results indicate that the presence of aluminum in solution retards the preclpitation of iron and molybdenum and Increases the amount of calcium carbonate needed for neutralization. The larger the concentration of aluminum in solution, the greater the extent to which the precipitation is retarded and the larger the amount of calcium carbonate which is required in order to make the precipitation. Previous results indicated that when 5.0 grams of $\mathrm{Fe}^{+++}$per liter is present in solution, complete precipitation of the molybdenum could be made at a pH of 3.4 with 12 grams $\mathrm{CaCO}_{3}$ per liter of solution. However, when 4.0 grams $\mathrm{Al}_{2} \mathrm{O}_{3}$ per liter was present in this solution, 0.017 gram Mo per Ifter and 0.13 gram $\mathrm{Fe}^{+++}$per liter remained in solution even at a pH of 3.5. By raising the $\mathrm{pH}$ to 4.1 , it is possible to precipitate 99.8 per cent of the molybdenum and 99.9 per cent of the iron; but in so doing about 95 per cent of the aluminum is also preaipitated and the calcium carbonate requirement is increased almost threefold to 33.0 grams $\mathrm{CaCO}_{3}$ per liter of solution. This precipitation of aluminum along with the iron and molybdenum results in greater reagent costs for both neutralization of the liquor and repulping of the precipitate, and also presents the problem of a buildup of this constituent if a recycling procedure is used.

During this investigation involving the effect of aluminum, the possible existence of a molybdenum-aluminum complex was encountered. When aluminum and molybdenum were mixed in solution prior to the addition of the ferric iron, the molybdenum was only partially precipitated with the ferric iron; while when the iron and molybdenum were mixed in solution prior to the addition of aluminum, the molybdenum was completely precipitated with the ferric 1ron. This leads to the bellef that molybdenum and iron form a complex ion in solution and that this formation must take place for the molybdenum to be precipitated with the ferric iron. If some of the molybdenum in solution complexes with some other ion or lons other than ferric lons, as in the presence of aluminum or silicate, then it would not be precipitated.

In order to test the effect of temperature on this possible aluminum-molybdenum complex, a solution was prepared by mixing the aluminum and molybdenum first and then adding ferric iron. The solution contained 1.0. gram Mo per liter, 18 grams $\mathrm{Al}_{2} \mathrm{O}_{3}$ per liter and 5.0 grams $\mathrm{Fe}^{+++}$per liter. Precipitations were made at ambient temperature, 50 and $100^{\circ} \mathrm{C}$. The results of these tests are presented below in Table VII. 
Table VII. Effect of Temperature on Molybdenum-Aluminum Complex

Head Assay: $\mathrm{Al}_{2} \mathrm{O}_{3}, 18 \mathrm{~g} / 1 ; \mathrm{Mo}, 1.0 \mathrm{~g} / 1 ; \mathrm{Fe}^{+++}, 5.0 \mathrm{~g} / 1$

\begin{tabular}{|c|c|c|c|c|c|c|c|}
\hline \multirow[b]{2}{*}{$\mathrm{T}^{\circ} \mathrm{C}$} & \multirow[b]{2}{*}{$\mathrm{pH}$} & \multicolumn{2}{|c|}{$\frac{\text { Filtrate Assay }}{\text { - Grams/Llter }}$} & \multirow[b]{2}{*}{ Mo } & \multicolumn{3}{|c|}{ \& Precipitated } \\
\hline & & $\overline{\mathrm{Al}_{2} \mathrm{O}_{3}}$ & $\mathrm{Fe}^{+++}$ & & $\mathrm{AI}_{2} \mathrm{O}_{3}$ & $\mathrm{Fe}^{+++}$ & Mo \\
\hline $\begin{array}{l}\text { A } \\
50 \\
100\end{array}$ & $\begin{array}{l}4.1 \\
3.6 \\
3.0\end{array}$ & $\begin{array}{l}0.60 \\
0.20 \\
0.40\end{array}$ & $\begin{array}{l}0.004 \\
0.006 \\
0.007\end{array}$ & $\begin{array}{l}0.64 \\
0.028 \\
0.007\end{array}$ & $\begin{array}{l}96.7 \\
98.9 \\
97.8\end{array}$ & $\begin{array}{l}99.9 \\
99.9 \\
99.9\end{array}$ & $\begin{array}{l}36.0 \\
97.2 \\
99.3\end{array}$ \\
\hline
\end{tabular}

It appears that increasing the temperature breaks down the aluminummolybdenum complex and aids in the formation of the iron-molybdenum precipitate. This 18 indicated by the fact that at $100^{\circ} \mathrm{C}$ all but 0.7 per cent of the molybdenum was precipitated, in contrast to only 36 per cent of the molybdenum being precipitated at ambient temperature.

\section{COMPOSITION OF THE PRECIPITATE}

Raising the pH of a strongly acidic solution containing ferric iron and molybdenum results in the formation of a yellow precipitate. The pH at which the initial precipitation begins is dependent upon the ratio of the concentrations of iron and molybdenum in solution. The results presented below in Table VIII illustrate this point.

Table VIII. Effeot of the Molar Ratio of Iron to Molybdenum on the $\mathrm{pH}$ of Initial Precipitation

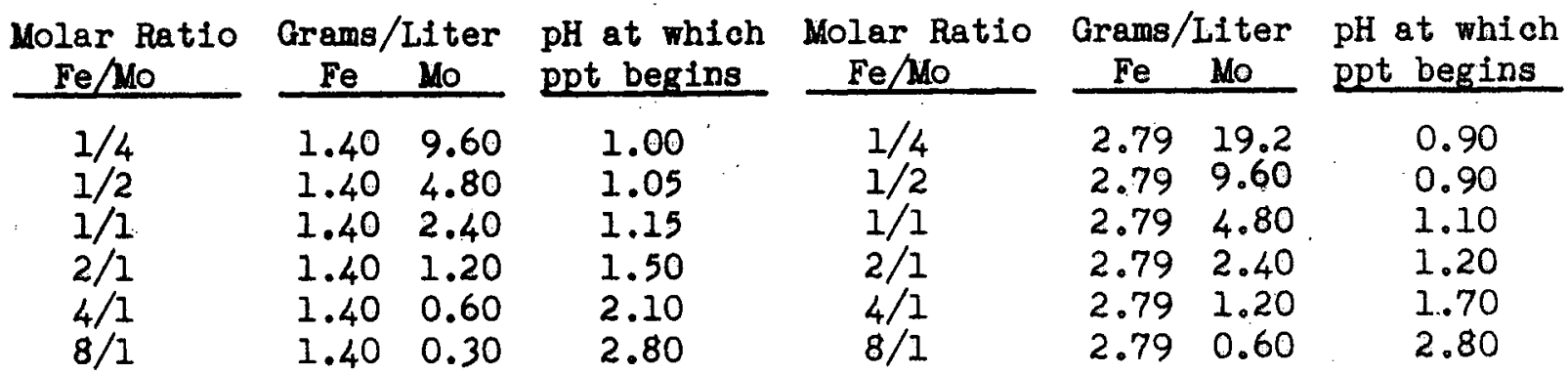


WIN -48

$-13-$

These results show that as the ratio of iron to molybdenum in solution increases, the $\mathrm{pH}$ at which the precipitation begins increases. It should also be noted that at an $8 / 1$ ratio of iron to molybdenum, precipitation does not take place until a $\mathrm{pH}$ of 2.8 is reached, this is the $\mathrm{pH}$ at which ferric iron would normally begin to precipitate.

Precipitations were made at several $\mathrm{pH}$ values from solutions which contained a $4 / 1,2 / 1$, and $1 / 1$ molar ratio of molybdenum to 1ron. These precipitates were dried at $110^{\circ} \mathrm{C}$ and analyzed for iron and molybdenum. Results of these tests are reported in Table IX: These results indicate that no definite composition can be assigned to the precipitate. The higher the ratio of molybdenum to iron present in solution, the higher the ratio of molybdenum to iron present in the precipitate for any given $\mathrm{pH}$ value. Iikewise, the higher the $\mathrm{pH}$ at which precipitation is made, the lower the ratio of molybdenum to iron present in the precipitate. These facts indicate that perhaps more than one type of compound is being formed. The lower ratios of molybdenum to iron present in the precipitates made at $\mathrm{pH}$ values of 3.0 and 3.5 may be due to the precipitation of iron as ferric hydroxide. A brown color is imparted to the precipitates at these $\mathrm{pH}$ values and this brownish color becomes more pronounced as the ratio of molybdenum to iron in solution decreases; this fact would seem to indicate that at least some of the iron was being precipitated as ferric hydroxide.

\section{RECOVERY OF COPRECIPITATED URANIUM}

The precipitation of iron and molybdenum from a uranium pregnant acid leach liquor results in some of the uranium being coprecipitated. In order to determine how much uranium would be removed from solution and some of the factors which affect this coprecipitation, a series of tests were made on solutions contalning iron, molybdenum, and uranium. Precipitations were made from solutions which contained 1.0 gram $0_{308}$ per liter, 1.0 gram Mo per liter, and various amounts of iron at $\mathrm{pH}$ values of $2.8,3.2$ and 3.6 . The results of these tests are presented in Table $X$. These results indicate that the amount of uranium coprecipitated is dependent on both the iron concentration and the $\mathrm{pH}$. The higher the iron concentration in solution, the greater the amount of uranium which will be removed during preclpitation. Also, the higher the $\mathrm{pH}$ at which preoipitation is made, the greater the amount of uranium removed. The effect of $\mathrm{pH}$ is not simply a function of the amount of iron precipitated. In a solution containing 10 grams of $\mathrm{Fe}^{+++}$per 11 ter at a $\mathrm{pH}$ of $2.8,95 \mathrm{per}$ cent of the iron is preolpitated and 3.9 per cent of the $\mathrm{U}_{3} \mathrm{O}_{8}$ is removed. While at $8 \mathrm{pH}$ of $3.6,99.9$ per cent of the iron is precipitated and 17.2 per cent of the $\mathrm{U}_{3} \mathrm{O}_{8}$ is removed. 
To test the effect of temperature on the coprecipitation of uranlum with iron and molybdenum, precipitations were made at ambient temperature, 50,75 , and $100^{\circ} \mathrm{C}$ from solution containing 1.0 gram $\mathrm{U}_{3} \mathrm{O}_{8}$ per liter, 1.0 gram of Mo per liter, and 5.0 grams of $\mathrm{Fe}^{+++}$per liter. The solutions were raised to a $\mathrm{pH}$ necessary to insure the precipitation of the molybdenum. Results of these tests are presented below in Table XI.

Table XI. Effect of Temperature on the Coprecipitation of Uranium

Head Assay: $U_{3} \mathrm{O}_{8}, 1.0 \mathrm{~g} / 1 ; \mathrm{MO}, 1.0 \mathrm{~g} / 1 ; \mathrm{Fe}^{+++} 5.0 \mathrm{~g} / 1$

\begin{tabular}{|c|c|c|c|c|c|c|}
\hline \multirow[b]{2}{*}{$\mathrm{T}^{\circ} \mathrm{C}$} & \multirow[b]{2}{*}{$\mathrm{pH}$} & \multicolumn{3}{|c|}{$\frac{\text { Filtrate Assay }}{\text { Grams/Liter }}$} & \multirow{2}{*}{$\frac{\text { Precipitate }}{\mathrm{H}_{3} \mathrm{O}_{8}}$} & \multirow[b]{2}{*}{$\mathrm{U}_{3} \mathrm{O}_{8}$ Removed } \\
\hline & & $\mathrm{U}_{3} \mathrm{O}_{8}$ & $\mathrm{Fe}^{+++}$ & Mo & & \\
\hline $\begin{array}{l}\text { A } \\
50 \\
75 \\
100\end{array}$ & $\begin{array}{l}3.6 \\
3.1 \\
2.9 \\
2.7\end{array}$ & $\begin{array}{l}0.85 \\
0.92 \\
0.95 \\
0.98\end{array}$ & $\begin{array}{l}0.007 \\
0.004 \\
0.015 \\
0.045\end{array}$ & $\begin{array}{l}0.001 \\
0.001 \\
0.001 \\
0.002\end{array}$ & $\begin{array}{l}0.65 \\
0.29 \\
0.089 \\
0.036\end{array}$ & $\begin{array}{r}13.8 \\
7.0 \\
2.1 \\
0.9\end{array}$ \\
\hline
\end{tabular}

These results show that as the temperature at which the precipitate is made increases, the amount of uranium removed with the precipitate decreases. When the preclpitation was made at $100^{\circ} \mathrm{C}$, less than 1 per cent of the total amount of uranium was coprecipitated.

To test the effect of the uranium concentration on its coprecipitation from solution with iron and molybdenum, precipitations were made from solutions containing $1.0 \mathrm{gram}$ of Mo per liter, 5.0 grams of $\mathrm{Fe}^{+++}$per Iiter, and various amounts of uranium at a $\mathrm{pH}$ of 3.6 and at ambient temperature. Results of these tests are presented in Table XII, below.

Table XII. Effect of Uranium Concentration on the Amount of Uranium Coprecipitated

Head Assay: $\mathrm{Mo}, 1 \mathrm{~g} / 1 ; \mathrm{Fe}^{+++}, 5.0 \mathrm{~g} / 1$

\begin{tabular}{|c|c|c|c|}
\hline $\begin{array}{l}\text { Head Assay } \\
\qquad \mathrm{U}_{3} 0_{8} / 1\end{array}$ & $\begin{array}{l}\text { Filtrate Assay } \\
\mathrm{g} \mathrm{U}_{3} 0_{8} / 1 \\
\end{array}$ & $\begin{array}{l}\text { Precipitate } \\
\quad \% \mathrm{U}_{3} \mathrm{O}_{8}\end{array}$ & $\begin{array}{r}\$ \mathrm{U}_{3} \mathrm{O}_{8} \\
\text { Removed } \\
\end{array}$ \\
\hline $\begin{array}{l}1.58 \\
1.00 \\
0.50 \\
0.24\end{array}$ & $\begin{array}{l}1.32 \\
0.85 \\
0.42 \\
0.20\end{array}$ & $\begin{array}{l}0.86 \\
0.65 \\
0.29 \\
0.23\end{array}$ & $\begin{array}{l}14.3 \\
13.8 \\
14.2 \\
19.1\end{array}$ \\
\hline
\end{tabular}


These results indicate that there is no significant difference in the percentage of uranium removed as the concentration of $\mathrm{U}_{3} \mathrm{O}_{8}$ in solution is varied.

As has already been shown, uranium is removed from solution with the precipitation of iron and molybdenum. To test the effectiveness of an acid repulp in recovering the uranium from the precipitate, a series of preoipitations were made from solutions containing $1.0 \mathrm{gram} \mathrm{U}_{3} \mathrm{O}_{\mathrm{g}}$ per liter, $1.0 \mathrm{gram}$ Mo per liter, and 5.0 grams $\mathrm{Fe}^{+++}$per liter at' both ambient temperature and $100^{\circ} \mathrm{C}$. The resulting precipitates were then repulped for one hour at a predetermined $\mathrm{pH}$ through the addition of dilute sulfuric acid. These repulps were made over a range of $\mathrm{pH}$ values at both ambient temperature and $100^{\circ} \mathrm{C}$. Four possible combinations of precipitation and repulp were studied: (1) precipitation at ambient temperature and repulp at ambient temperature, (2) precipitation at ambient temperature and repulp at $100^{\circ} \mathrm{C}$, (3) precipitation at $100^{\circ} \mathrm{C}$ and repulp at amblent temperature, and

(4) precipitation at $100^{\circ} \mathrm{C}$ and repulp at $100^{\circ} \mathrm{C}$. The results of these tests are reported in Table XIII. These results indicate that the uranium can be successfully recovered from the precipitate by an acid repulp. Nearly complete rejection of molybdenum was accomplished with a loss of 0.1 to 0.25 per cent of the uranium in the feed liquor.

\section{REMOVAL OF YOLYBDENUM FROM AMBROSIA LAKE LEACH LIQUORS}

Molybdenum Precipitation and Ion Exchange - Batch Tests

The neutralization of acid leach Ifquor from Ambrosia Lake Sample 331-1 with calcium carbonate to a pH of 3.6 results in almost complete removal of the molybdenum from the liquor. Analysis of the leach liquor after preclpitation indicated that only 0.001 gram Mo per liter, 0.03 gram Fe+++ per liter, and 10.0 grams $\mathrm{SO}_{4}=$ per liter remain in solution so that a liquor which is readily amenable to ion exchange is obtained.

To 1llustrate the advantage of precipitating the iron and molybdenum prior to ion exchange, batch adsorption tests were made on leach liquor prepared from ore Sample 331-1. The leach liquor was split into three batches, the first batch (A) was adjusted to a $\mathrm{pH}$ of 1.5 ; the second batch (B) was neutralized to a pH of 3.6 with calcium carbonate to remove the iron and molybdenum, and then was adjusted to a $\mathrm{pH}$ of 1.5 with sulfurio acid; and the third batch (C) was also neutralized to a pH of 3.6 with calcium carbonate to remove the iron and molybdenum and the $\mathrm{pH}$ was adjusted to 3.2 to prevent any further hydrolysis. Partial chemical analysis of the three batches of Ilquor are presented on the following page. 


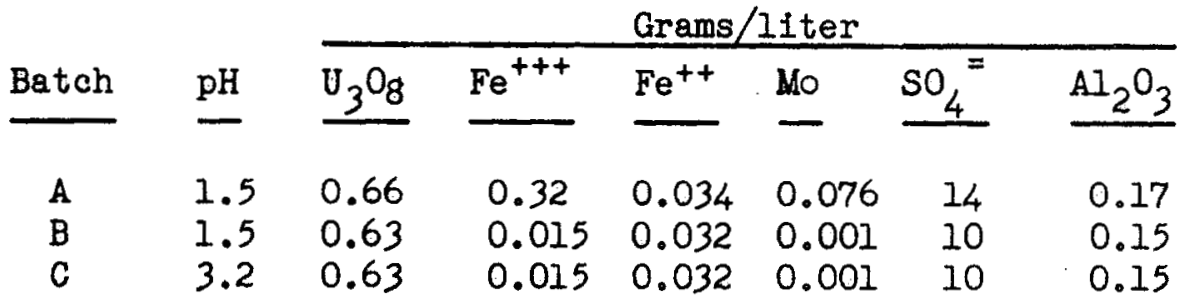

One thousand $\mathrm{ml}$ of each batch of liquor was contacted with $10 \mathrm{ml}$ of fresh IRA-400 resin in the sulfate form. Samples were taken at $1,2,4,8,16,32,64,128$ and 256 minutes. The amount of uranium adsorbed was plotted against the contact time and the three curves obtained are presented in Figure 1. These curves show that the adsorption of uranium from this liquor is more rapid at a $\mathrm{pH}$ of 3.2 than at a $\mathrm{pH}$ of 1.5. Also, the uranium adsorption is more rapid from the liquor from which the iron and molybdenum have been removed than from the liquor at the same $\mathrm{pH}$ which contains iron and molybdenum.

Saturation loadings on IRA-400 resin for the three batches of liquor were obtalned by column ion exchange. The retention times were 3 minutes for exhaustion and 10 minutes for elution. The eluant used was 1.0M sodium chloride adjusted to a $\mathrm{pH}$ of 1.0 with hydrochloric acid. Elution was complete in 10 bed volumes. The loadings based on the eluate assay are presented below:

\section{Batch}

A Containing Mo, $\mathrm{pH} 1.5$

B Mo Removed, $\mathrm{pH} 1.5$

C Mo Removed, pH 3.2 g U U ${ }_{3}{ }_{8} / 1$ WSR

56.3

71.1

89.5

Considerably higher loadings. were obtalned when the lon exchange was made at a $\mathrm{pH}$ of 3.2 , as compared to the loadings obtained when the Ion exchange was made at 1.5. The removal of molybdenum from the leach liquor, also led to higher saturation loadings when compared to the liquor at the same pH containing molybdenum.

\section{Cyclic Leaching and Molybdenum Precipitation}

A series of oyollc leaching and precipitation tests was made on ore Sample 331-1. The ore was leached with $175 \mathrm{Ibs}_{2} \mathrm{SO}_{4}$ and 10 Ibs $\mathrm{MnO}_{2}$ per ton of ore. The resulting leach liquor was neutral- 
WIN -48

-17 -

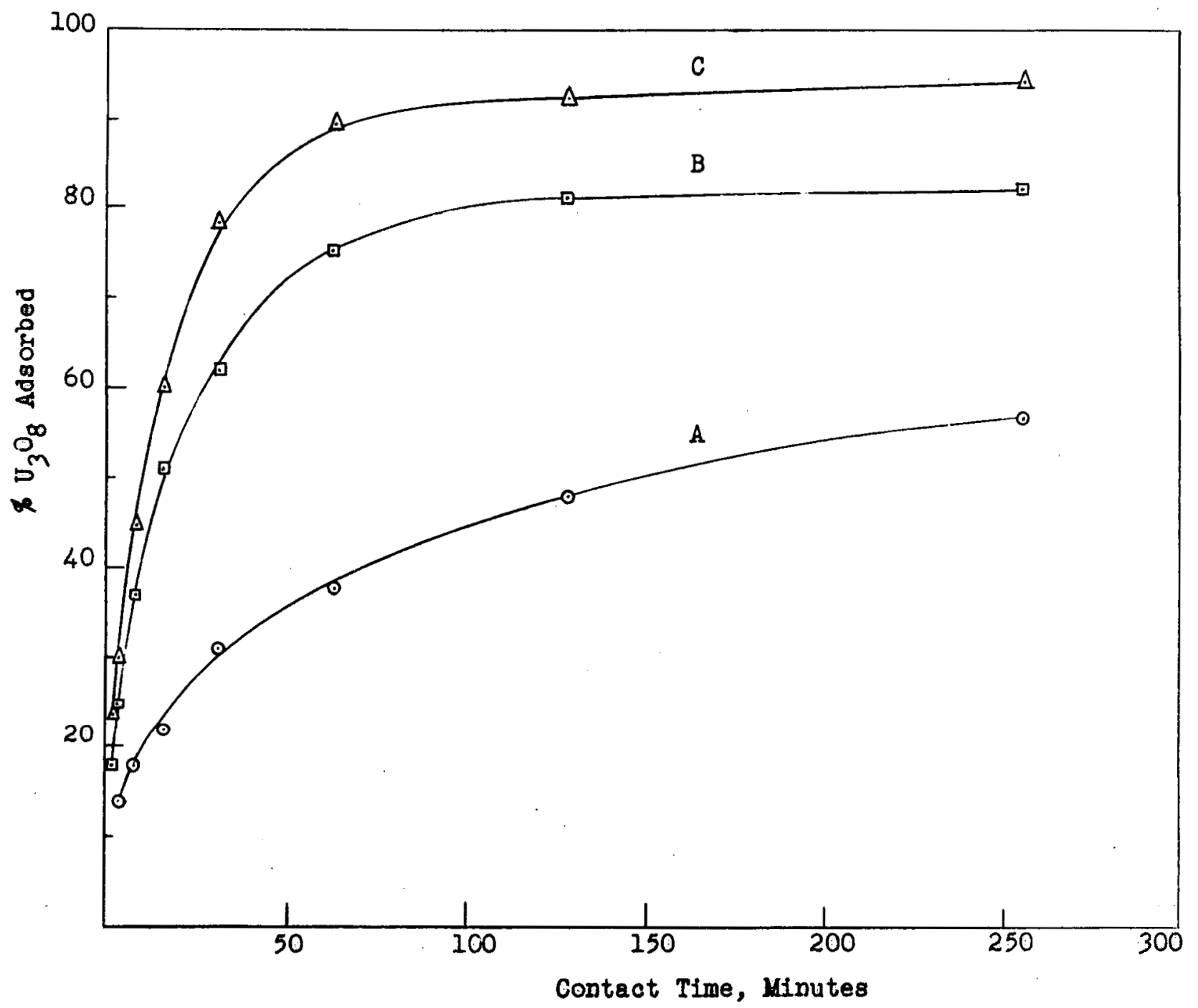

Figure 1. Adsorption of uranium from Ambrosia Lake District Leach Iiquor (Sample 33I-1)

A. $\mathrm{pH}$ adjusted to 1.5

B. Neutraifized to $\mathrm{pH} 3.6$ and $\mathrm{pH}$ adjusted to 1.5

C. Neutralized to $\mathrm{pH} 3.6$ and $\mathrm{pH}$ adjusted to 3.2 
Ized to a pH of 3.6 with calcium carbonate to precipitate molybdenum and iron. Previous test work had shown that about 2 per cent of the uranium is removed from the liquor during this precipitation. Therefore, in an attempt to recover this precipitated uranium, the precipitate was repulped in the next acld leach pulp, subsequent to the leaching. This procedure has the advantage that in addition to the recovery of uranium, the $\mathrm{pH}$ of the liquor is higher than it would ordinarily be and therefore requires less calcium carbonate for neutralization. In these tests the iron precipitate was not washed, in order to keep the uranium concentration of the pregnant liquor as high as possible, and therefore the amount of uranium held by the precipitate was larger than the 2 per cent normally coprecipitated. Since this precipitate was recycled to the next acid leach pulp, washing was not necessary.

Seven leaching and neutralization tests were made. The overall calcium carbonate consumption was only about 25 lbs per ton of ore. The uranium extraction varied from 91.4 to 96.0 per cent. Due to the recycling of the neutralization precipitate there is an increase in the iron and molybdenum content of the acid leach filtrates. The iron concentration increased from 0.5 to 2.13 grams per liter while the molybdenum concentration inereased from 0.047 to 0.083 gram per liter. In order to prevent an accumulation of these constituenti, it rould be necessary to either bleed the circuit periodically or to discard the precipitate from the system at certain intervals. In these tests, after seven cycles, the iron precipitate welghed only 9.5 grams and assayed 0.2 per cent $\mathrm{U}_{3} \mathrm{O}_{8}$. The amount of uranium which would be lost, if it were decided to discard the precipitate at this point, would amount to only 0.2 per cent of the total amount of uranium in the ore treated. Data for the seven cycles are presented in Table XIV.

REMOVAL OF MOLYBDENTM FROM LIGNITE LEACH LIQUORS

Neutral ization of Leach Liquors from Several Lignites

Precipitation tests for the removal of molybdenum were made on leach liquors prepared from the following ashed samples:

Sample No.

$185-8$

$185-16$

$185-18$

$185-19$

$185-21$
Description

A. S. \& R. Co. Edgemont Lignite Bryco Mining Co. Hilltop

Peter Kiewit Ore Farmington Lignite Section 27 Northgate Iignite Smith No. I 
Molybdenum can be successfully removed from liquors prepared from ore Samples 185-8, 185-19 and 185-21, with only 1 to 2 ppm remaining in solution. However, on leach liquors prepared from ore samples $185-16$ and $185-18$, between 10 and $20 \mathrm{ppm}$ of molybdenum remained in solution. The precipitate from 185-8 leach liquor was difficult to filter and contained 20 per cent of the uranium in the liquor. This is probably due to the large amount of ferric iron present in the liquor. The precipitate from the other liquors all filtered readily and contained 12 per cent or less of the uranium originally in the liquor. Chemical assays in grams per liter of the liquors before and after precipitation are presented in Table XV.

\section{Molybdenum Removal and Ión Exchange}

Ion exchange amenability tests were made on liquors prepared from ore Samples 185-16 and 185-18. Since the removal of molybdenum from these liquors by precipitation is not complete, a charcoal scavenger column was employed prior to the ion exchange columns in order to remove the small amounts of molybdenum remaining in the liquors.

\section{Bryco Hilltop Sample $185-16$}

Minus 10-mesh muffle roasted ore was leached at 50 per cent solids for six hours at $75^{\circ} \mathrm{C}$ with 677 lbs of $\mathrm{H}_{2} \mathrm{SO}_{4}$ per ton of ash. After leaching, the pulp was diluted to approximately 30 per cent solids and flocculated with Separan. The diluted pulp was filtered and washed with hot water to a final volume of four liters per kilogram of ash. Uranium extraction, based on the residue assay, was 85 per cent.

The leach liquor was oxidized with potassium permanganate to an emf of $-540 \mathrm{mv}$. It was then heated to $50^{\circ} \mathrm{C}$, and calcium carbonate was added until a pH of 3.5 was reached. Neutralization requirements were 400 . Ibs of $\mathrm{CaCO}_{3}$ per ton of ash. The precipitate was filtered and water washed. Filtration characteristios were excellent. About 98 per cent of the molybdenum was removed by the precipitation. Practically all of the iron was precipitated and about 64 per cent of the sulfate was removed as shown below: 
Precipitation of Molybdenum from $185-16$ Leach Liquor

\begin{tabular}{|c|c|c|c|c|c|c|c|c|}
\hline & \multirow[b]{2}{*}{ pH } & \multirow[b]{2}{*}{$\operatorname{Ein} f(n v)$} & \multicolumn{6}{|c|}{ Grams/Liter } \\
\hline & & & $\overline{\mathrm{U}_{3}} \underline{\mathrm{O} g}$ & Mo & $\underline{\mathrm{Fe}^{+++}}$ & $\mathrm{Fe}^{++}$ & $\mathrm{SO}_{4-}^{=}$ & $\mathrm{Al}_{2} \mathrm{O}_{3}$ \\
\hline Before neutralization & 1.5 & $-420^{1}$ & 1.10 & 0.52 & 2.66 & 1.29 & 77.7 & 19.0 \\
\hline After neutralization & 3.7 & -540 & 1.04 & 0.012 & 0.01 & 0.07 & 28.0 & 7.5 \\
\hline
\end{tabular}

The precipitate from the neutralization was repulped for the recovery of uranium. A pH of 3.2 was maintained for one hour by the addition of sulfuric acld. The precipitate before repulp assayed 0.074 per cent $\mathrm{U}_{3} \mathrm{O}_{8}$; and after the repulp, assayed 0.016 per cent $\mathrm{U}_{3} \mathrm{O}_{8}$. The amount of uranium remaining in the precipitate is equal to 1.2 per cent of the total amount in the liquor before precipitation. Analysis of the filtrate indicated that about 10 per cent of the molybdenum and iron was redissolved during the repulping.

Cyclic ion exchange test work was done on the treated liquor. The ion exchange system consisted of 3 columns of $25 \mathrm{ml}$ of wet settled IRA-400 resin. Two columns were run to exhaustion while one was being eluted. The leach liquor was passed through a scavenger column containing $25 \mathrm{ml}$ of wet settled Columbia activated charcoal prior to the ion exchange resin. This charcoal column removes the small amount of molybdenum remaining in the liquor after the precipitation. The leach liquor was adjusted to a $\mathrm{pH}$ of 3.0 with sulfuric acid. Retention times were 3 minutes for exhaustion and 10 minutes for elution. The eluant was l.OM sodium chloride adjusted to a pH of 1.0 with sulfuric acid. Four complete cycles of exhaustion and elution of each column in the system were run. The average $\mathrm{U}_{3} \mathrm{O}_{8}$ loading was 92 grams $\mathrm{U}_{3} \mathrm{O}_{8}$ per liter of wet settled resin, with no apparent molybdenum poisoning. A total of approximately 20 ifters of liquor were passed over the charcoal scavenger column. The effluents for this colum assayed 0.004 gram Mo per liter. The ion exchange data ls sumbarized in Table XVI. 
WIN -48

Table XVI

Cyclic Ion Exchange of 185-16 Lignite

Leach Liquor

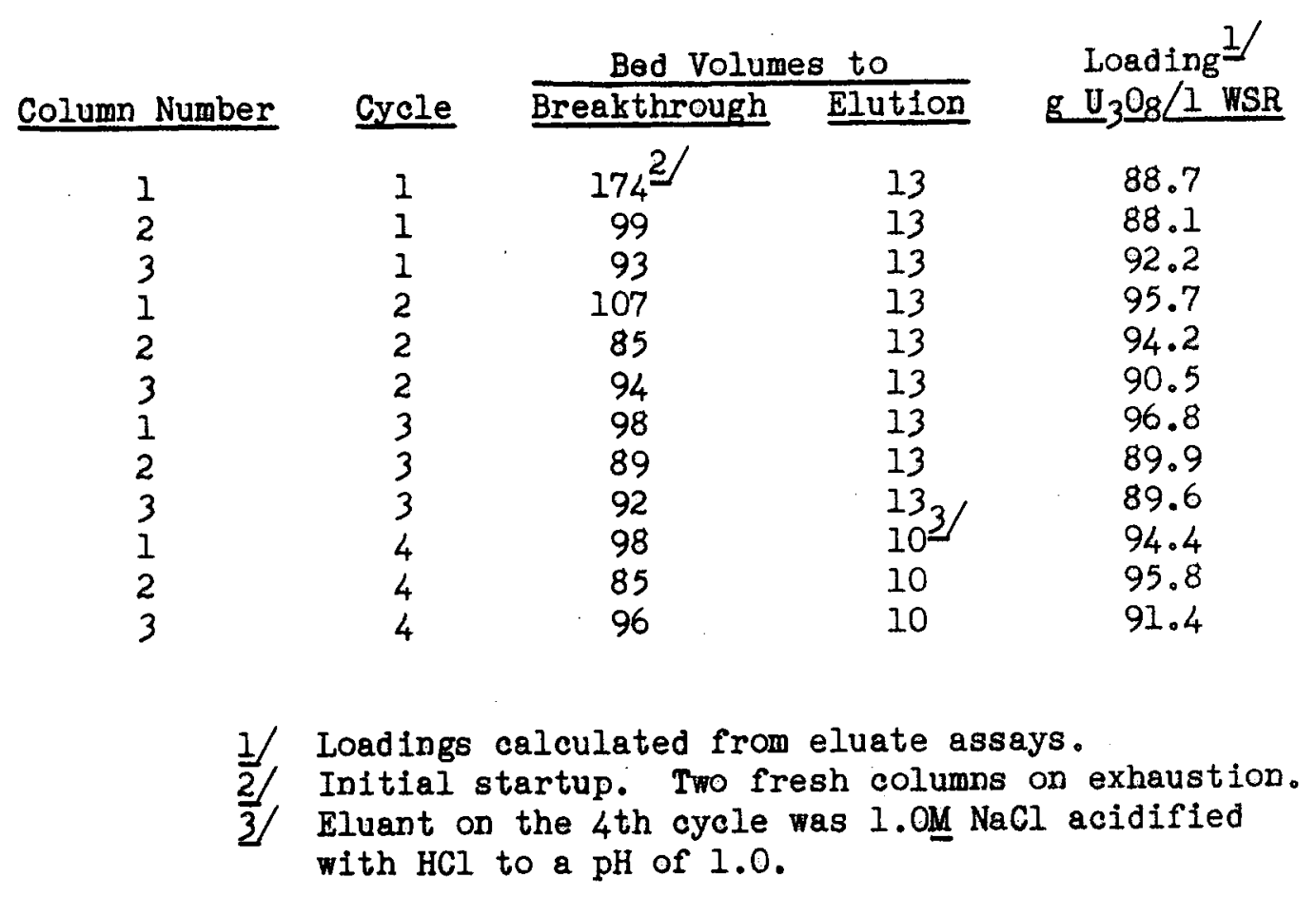

Peter Kiew1t Sample 185-18

Minus 10-mesh roasted ore was leached at 50 per cent solids for $81 \mathrm{x}$ hours at $75^{\circ} \mathrm{C}$ with 1100 lbs of $\mathrm{H}_{2} \mathrm{SO}_{4}$ per ton of ash. After leaching, the pulp was diluted to approximately 30 per cent solids and flocculated with Separan. The diluted pulp was filtered and washed with hot water to a final volume of four liters per kilogram of ash. The uranium extraction, based on the residue assay, was 88 per cent.

The leach liquor was oxidized with potassium permanganate to an emf of $-540 \mathrm{mv}$. It was then heated to $55^{\circ} \mathrm{C}$ and calcium carbonate was added to a pH of 3.7. This neutralization produced a precipitate which removed about 98 per cent of the molybdenum and iron, 56 per cent of the sulfate, and 12 per cent of the uranium. This uranium, however, can be recovered by a repulp of the precipitate. 
Precipitation of Molybdenum from 185-18 Leach Liquor

\begin{tabular}{|c|c|c|c|c|c|c|c|c|}
\hline & - & $\operatorname{Emf}(\operatorname{mv})$ & $\underline{\mathrm{U}}_{3} \mathrm{O}_{8}$ & Mo & $\mathrm{Fe}^{+++}$ & $\mathrm{Fe}^{++}$ & $\mathrm{SO}_{4-}=$ & $\mathrm{Al}_{2} \underline{\mathrm{O}}_{3}$ \\
\hline & 1.5 & & 0.98 & 0.42 & 7.70 & 0.77 & 90.0 & 8.3 \\
\hline 0 & 3. & -360 & .86 & 0.01 & 0.02 & .10 & 0 & 8 \\
\hline
\end{tabular}

I/ emf of liquor before oxidation

The precipitate from the neutralization was repulped for one hour with 552 grams of $\mathrm{H}_{2} \mathrm{SO}_{4}$ (94 lbs per ton of ash) to a terminal pH of 3.3. The precipitate assayed 0.10 per cent $\mathrm{U}_{3} \mathrm{O}_{8}$ before repulp and 0.02 per cent $\mathrm{O}_{3} \mathrm{O}_{8}$ after repulp. The amount of uranium remaining in the precipitate is equal to 2.5 per cent of the total amount of uranium in the liquor before precipitation. The filtrate from the repulp showed that about 10 per cent of the molybdenum and iron was redissolved during the repulping. The filtration characteristics were very poor.

Cyclic ion exchange test work was done on the treated liquor. The ion exchange system was the same as that used on the 185-16 leach liquor. The leach liquor was adjusted to a $\mathrm{pH}$ of 3.0 with sulfuric acid. The retention time was 3 minutes for exhaustion and 10 minutes for elution. The eluant was 1.0M sodium chloride acidified with hydrochloric acid to a pH of 1.0. A total of 26.6 liters or 1064 bed volumes were treated in the charcoal scavenger column. The molybdenum assays of the effluents ranged from 0.002 to 0.003 gram per liter. This molybdenum concentration had no apparent effect on the resin capacity.

Uranium loadings were approximately $90 \mathrm{~g}$ of $\mathrm{U}_{3} \mathrm{O}_{8} / 1 \mathrm{WSR}$. The ion exchange data is summarized in Table XVII.

Táble XVII

Cyclic Ion Exchange of 185-18 Lignite Leach Liquor

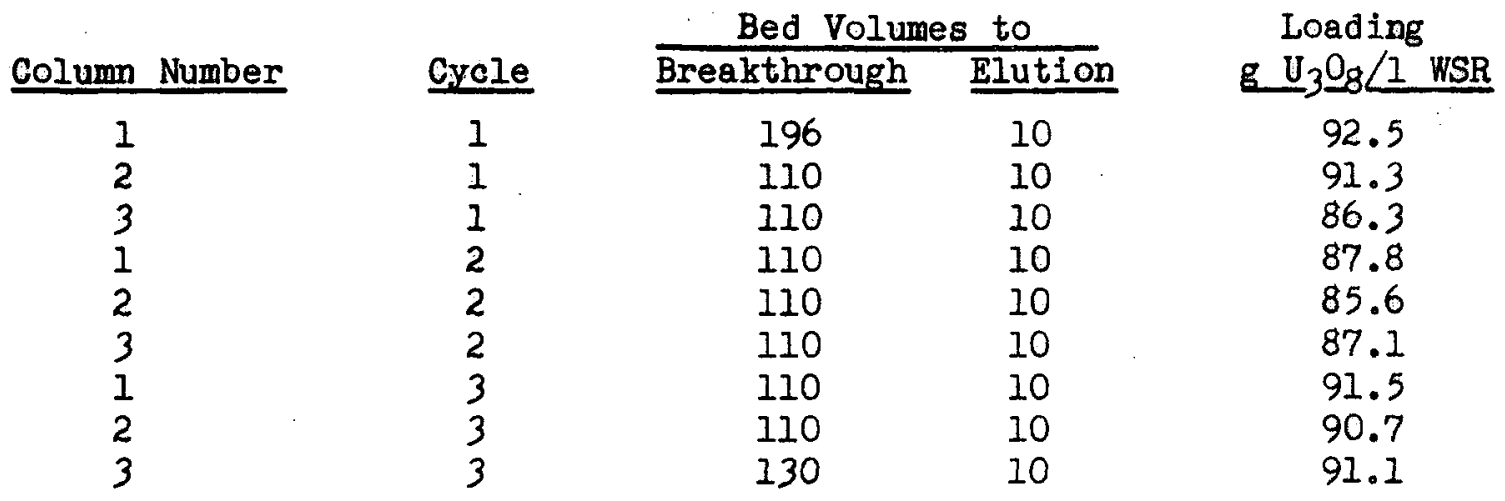


WIN -48

Effect of Recyoling Repulp Solution

Since good results were obtained when cyclic ion exchange tests were conducted on lignite leach liquor from which the molybdenum had been precipitated, it now remained to determine the effect of recycling the filtrate, resulting from an acid repulp of the precipitate, back to the next acid leach. This is made necessary in order to recover the uranium which was removed with the precipitate. Ore sample 185-16 was used for these tests. The following procedure was used:

Leaching Conditions. Minus 10-mesh ash was leached for 6 hours at $75^{\circ} \mathrm{C}$ and 50 per cent solids with $700 \mathrm{Ibs}_{2} \mathrm{SO}_{4}$ per ton of ash. In tests 2, 3 and 4, repulp solution was used in the leach and to dilute the pulp after leaching.

Precipitation. The leach liquor was heated to $50^{\circ} \mathrm{C}$ and calcium carbonate was added until the desired $\mathrm{pH}$ was reached. The precipitate was filtered and the filtrate was ion exchanged.

Repulp. The precipitates were repulped for one hour with the addition of sulfuric acid. The filtrates from these repulps were recycled to the next acid leach. The residues were discarded.

Ion Exchange. The IIquor after precipitation was adjusted to a $\mathrm{pH}$ of 3.0 with sulfuric acid. Prior to ion exchange, the liquor was passed through a molybdenum scavenger column containing activated charcoal in order to remove any molybdenum remaining in the liquor. For each leaching test, one saturation loading on IRA-400 resin was obtained. Retention times were 3 minutes on exhaustion and 10 minutes on elution. The eluant used was $1.0 \mathrm{M}$ sodium chloride acldifled to a pH of 1.0 with hydrochloric acid。 Complete test data are summarized in Table XVIII.

The test data show that there is no increase of iron and molybdenum in the acid leach filtrate due to the recycling procedure. This may be due to the fact that partial precipitation of these elements takes place during the leaching. The terminal pH increased with each leaching cycle, and this increase in $\mathrm{pH}$ would aid in the preoipitation of iron and molybdenum. The ion exchange data shows no apparent effect because of the recycling of the repulp filtrates. The uranium saturation loadings increased with each successive cycle, and this was probably oue to the increase in uranium concentration of the feed liquor over the first three cycles. However, there was a very substantial buildup of aluminum in the acid leach filtrates. Apparently, the precipitated aluminum was partially redissolved during the repulping operation and was returned to the next acid leach. The aluminum in the acid leach filtrates increased 
WIN -48

$-24-$

from 19.5 grams $\mathrm{Al}_{2} \mathrm{O}_{3}$ per liter in the first cycle to 53.0 grams $\mathrm{Al}_{2} \mathrm{O}_{3}$ per liter in the fourth cycle. In the repulp filtrates, the $\mathrm{Al}_{2} \mathrm{O}_{3}$ increased from 16.1 to 65.0 grams per liter over the four cycles. The calcium carbonate necessary to neutralize the leach liquors increased from 380 to 650 lbs per ton of ash and the sulfuric acid used in the repulping step increased from 158 to 310 Ibs per ton of ash over the four cycles. This increase in reagent consumption can be attributed to the buildup of aluminum. in the system. It would appear, therefore, that a process of this type involving the recycling of a repulp filtrate would be impractical for this ore because of excessive reagent costs.

Precipitation of Molybdenum During Leaching

In all of the test work previously discussed, the molybdenum and iron had been precipitated by the addition of calcium carbonate to a clear solution. The possibility of controling the amount of molybdenum present in an acld leach liquor through. control of the leaching conditions has been studied. It should be noted that although the work done on this aspect of the problem was on a very limited scale, the results obtained.indicated that probably the most practical way of precipitating molybdenum in this manner would be through proper controlling of acid leaching conditions.

Leaching tests were made on roasted ore, Sample 185-19, at 70, 80,90 , and $98^{\circ} \mathrm{C}$ to determine what effect increasing the leaching temperature would have on the amount of molybdenum found in the filtrates. In order to give a terminal $\mathrm{pH}$ of about $1.5,550$ lbs of $\mathrm{H}_{2} \mathrm{SO}_{4}$ per ton of ash was used. Results of these tests are presented in Table XIX. The tests show that increasing the leaching temperature has no effect on the uranium extractions; however, the amounts of molybdenum and iron present in the filtrates decrease as the temperature increases. This decrease in molybdenum and iron concentration can be attributed to the fact that increasing the temperature causes precipitation of iron and molybdenum.

A series of leaching tests were made at $98^{\circ} \mathrm{C}$ on several lignite ore samples in order to test the effect of leaching $\mathrm{pH}$ on the molybdenum to be found in the filtrates. Leaching tests were made on roasted ore samples $185-19,-21$, and 25 . The amounts of acid used were varied in order to produce terminal leach $\mathrm{pH}$ values which would cover a range from 0.0 to 2.5 . The data presented in Tables XX, XXI and XXII show that the higher the pH of the leach, the lower the concentration of molyboenum in the filtrate. These results indicate that a leach liquor relatively free of molybdenum and ferric Iron can be produced by leaching lignite ash at a relatively high $\mathrm{pH}$ and at elevated temperature. 
A two-stage leaching circuit is suggested as a method of rejecting molybdenum and ferric iron from pregnant solutions in treating high molybdenum ores without resorting to the use of an excessive amount of reagents for neutralization. One stage would be a neutralizing leach made at a pH sufficiently high to precipitate the iron and molybdenum and render the liquor amenable to fon exchange; the second stage would be a strong acid leach necessary to obtain optimum uranium extraction.

\section{LITERATURE CITED}

1. Schiff, N. N., Hollis, E. T., Lower, G. G., U。 S. Atomic Energy Commission, ACCO 35 (1954).

2. Schiff, N. N., Viklund, H. I., Ibid., ACCO 46 (1954).

3. Quinlan, K. P., Barry, R. J., Ibid。, WIN-27 (1956)。 
Table I. Effect of $\mathrm{pH}$ on the Precipitation of Molybdenum Head Solution: Mo, $2.40 \mathrm{~g} / 1 ; \mathrm{Fe}^{+++}, 2.79 \mathrm{~g} / \mathrm{l}$

$\underline{\mathrm{pH}}$

1.5

2.0

2.5

3.0

3.2

3.4

3.6

3.8

4.0

4.5

5.0

6.0

7.0

8.0

9.0
Filtrate Assay

Grams/Liter

Mo $\mathrm{Fe}^{+++}$

$1.04 \quad 2.43$

$0.66 \quad 2.26$

$0.46 \quad 2.08$

$\begin{array}{ll}0.042 & 0.11\end{array}$

$0.016 \quad 0.03$

$0.012 \quad 0.014$

$0.009 \quad 0.004$

$0.010<0.001$

0.024

0.078

0.11

0.57

0.96

1.32

1.60
\% Precipitated

\begin{tabular}{ll} 
Mo & $\mathrm{Fe}^{+++}$ \\
\hline 56.7 & 12.9 \\
72.5 & 19.0 \\
80.1 & 25.4 \\
98.2 & 96.0 \\
99.3 & 98.9 \\
99.5 & 99.5 \\
99.6 & 99.9 \\
99.6 & 799.9 \\
99.0 & \\
96.7 & \\
95.4 & \\
76.4 & \\
60.0 & \\
45.0 & \\
33.3 &
\end{tabular}




\section{7}

\section{Table III}

Effect of Iron Concentration on the pH at which Molybdenum is Precipitated

\begin{tabular}{|c|c|c|c|c|}
\hline \multirow[b]{3}{*}{$\mathrm{DH}$} & \multicolumn{4}{|c|}{$2.0 \mathrm{~g} \mathrm{Fe} e^{+++} / 1$} \\
\hline & \multicolumn{2}{|c|}{ Filtrate Assay, g/1 } & \multicolumn{2}{|c|}{ \& Precipitated } \\
\hline & $\mathrm{Fe}$ & $M$ & $\mathrm{Fe}^{++\mathrm{F}}$ & Mo \\
\hline $\begin{array}{l}2.4 \\
2.6 \\
2.8 \\
3.0 \\
3.2 \\
3.4 \\
3.6\end{array}$ & $\begin{array}{l}1.25 \\
1.05 \\
0.45 \\
0.13 \\
0.041 \\
0.016 \\
0.002\end{array}$ & $\begin{array}{l}0.250 \\
0.153 \\
0.066 \\
0.027 \\
0.012 \\
0.006 \\
0.002\end{array}$ & $\begin{array}{l}37.5 \\
47.5 \\
77.5 \\
93.5 \\
97.9 \\
99.2 \\
99.9\end{array}$ & $\begin{array}{l}75.0 \\
84.7 \\
93.4 \\
97.3 \\
98.8 \\
99.4 \\
99.8\end{array}$ \\
\hline & \multicolumn{4}{|c|}{$10.0 \mathrm{~g} \mathrm{Fe}^{+++} / \mathrm{a}$} \\
\hline $\mathrm{pH}$ & \multicolumn{2}{|c|}{ Elltrate Assay, $\mathrm{g} / \mathrm{I}$} & \multicolumn{2}{|c|}{ \%Precipitated } \\
\hline $\begin{array}{l}2.4 \\
2.6 \\
2.8 \\
3.0 \\
3.2 \\
3.4 \\
3.6\end{array}$ & $\begin{array}{l}1.79 \\
0.50 \\
0.17 \\
0.073 \\
0.017 \\
0.008 \\
0.003\end{array}$ & $\begin{array}{r}0.151 \\
0.057 \\
0.022 \\
0.009 \\
0.001 \\
<0.001 \\
<0.001\end{array}$ & $\begin{array}{r}82.1 \\
95.0 \\
98.3 \\
99.3 \\
99.8 \\
>99.9 \\
>99.9\end{array}$ & $\begin{array}{r}84.9 \\
94.3 \\
97.8 \\
99.1 \\
99.9 \\
>99.9 \\
>99.9\end{array}$ \\
\hline
\end{tabular}

\begin{tabular}{|c|c|c|c|c|}
\hline \multirow[b]{2}{*}{$\mathrm{pH}$} & \multicolumn{4}{|c|}{$5.0 \mathrm{~g} \mathrm{Fe}+1$} \\
\hline & \multicolumn{2}{|c|}{ Eiltrate Assey, $\mathrm{g} / \mathrm{I}$} & $\frac{\text { Prec }}{\mathrm{Fe}}$ & $\frac{1 \text { tated }}{16}$ \\
\hline $\begin{array}{l}2.4 \\
2.6 \\
2.8 \\
3.0 \\
3.2 \\
3.4 \\
3.6\end{array}$ & $\begin{array}{l}1.84 \\
1.11 \\
0.41 \\
0.16 \\
0.038 \\
0.007 \\
0.003\end{array}$ & $\begin{array}{l}0.185 \\
0.117 \\
0.071 \\
0.029 \\
0.007 \\
0.001 \\
0.001\end{array}$ & $\begin{array}{r}63.2 \\
77.8 \\
91.8 \\
96.8 \\
99.2 \\
99.9 \\
>99.9\end{array}$ & $\begin{array}{l}81.5 \\
88.3 \\
92.9 \\
97.1 \\
99.3 \\
99.9 \\
99.9\end{array}$ \\
\hline & \multicolumn{4}{|c|}{$20.0 \mathrm{~g} \mathrm{Fe}^{+++} / 1$} \\
\hline $\mathrm{pH}$ & $\frac{\text { Filtrate }}{\mathrm{Fe}}$ & $\frac{\text { Assax, } g / I}{\frac{M 0}{1}}$ & $\frac{\text { P Prec }}{\mathrm{Fe}}$ & $\frac{\text { pitated }}{\mathrm{Mo}}$ \\
\hline $\begin{array}{l}2.4 \\
2.6 \\
2.8 \\
3.0 \\
3.2 \\
3.4\end{array}$ & $\begin{array}{l}1.04 \\
0.46 \\
0.13 \\
0.037 \\
0.009 \\
0.005\end{array}$ & $\begin{array}{r}0.069 \\
0.033 \\
0.012 \\
0.001 \\
<0.001 \\
<0.001\end{array}$ & $\begin{array}{r}94.8 \\
97.7 \\
99.4 \\
99.8 \\
>99.9 \\
>99.9\end{array}$ & $\begin{array}{r}93.1 \\
96.7 \\
98.8 \\
99.9 \\
>99.9 \\
>99.9\end{array}$ \\
\hline
\end{tabular}


Table IV. Effect of Temperature on the Precipitation of Molybdenum

\begin{tabular}{|c|c|c|c|c|c|c|c|c|}
\hline \multirow[b]{2}{*}{$\mathrm{pH}$} & \multicolumn{2}{|c|}{$\frac{\text { Filtrate As say }}{\text { g/1 at } 25^{\circ} \mathrm{C}}$} & \multicolumn{2}{|c|}{$\frac{\text { Filtrate Assay }}{\text { g/1 at } 50^{\circ} \mathrm{C}}$} & \multicolumn{2}{|c|}{$\frac{\text { Filtrate Assey }}{\mathrm{g} / 1 \text { at } 75^{\circ} \mathrm{C}}$} & \multicolumn{2}{|c|}{$\frac{\text { Filtrate Assay }}{\mathrm{g} / 1 \text { at } 100^{\circ} \mathrm{C}}$} \\
\hline & $\mathrm{Fe}^{+++}$ & Mo & $\mathrm{Fe}^{++t}$ & $\underline{\mathrm{MO}}$ & $\mathrm{Fe}^{++t}$ & $\underline{\mathrm{MO}}$ & $\mathrm{Fe}^{+++}$ & $\underline{\mathrm{MO}}$ \\
\hline 1.6 & & & & & & & 4.65 & 0.62 \\
\hline 1.8 & & & & & & & 3.50 & 0.17 \\
\hline 2.0 & & & & & 2.64 & 0.17 & 0.390 & 0.005 \\
\hline 2.2 & & & 1.50 & 0.065 & 1.22 & 0.045 & 0.061 & 0.003 \\
\hline 2.4 & 1.84 & 0.185 & 0.39 & 0.035 & 0.22 & 0.004 & 0.034 & 0.001 \\
\hline 2.6 & 1.11 & 0.117 & 0.13 & 0.009 & 0.071 & 0.001 & 0.012 & $<0.001$ \\
\hline 2.8 & 0.41 & 0.071 & 0.043 & 0.003 & 0.015 & $<0.001$ & & \\
\hline 3.0 & 0.16 & 0.029 & 0.015 & $<.001$ & 0.006 & $<0.001$ & & \\
\hline 3.2 & 0.038 & 0.007 & 0.004 & $<.001$ & & & & \\
\hline 3.4 & 0.007 & 0.001 & & & & & & \\
\hline 3.6 & 0.003 & 0.001 & & & & & & \\
\hline
\end{tabular}


Table VI. Effect of Aluminum On The Precipitation of Molybdenum

Test I Head Assay: $\mathrm{Al}_{2} \mathrm{O}_{3}, 4.0 \mathrm{~g} / \mathrm{I} ; \mathrm{Mo}, 1.0 \mathrm{~g} / 1 ; \mathrm{Fe}^{+++}, 5.0 \mathrm{~g} / 1$

\begin{tabular}{|c|c|c|c|c|c|c|c|}
\hline \multirow[b]{2}{*}{$\mathrm{pH}$} & \multicolumn{3}{|c|}{ Filtrate Assay } & $\% \operatorname{Pr} \epsilon$ & ipitat & & \multirow{2}{*}{$\frac{\mathrm{CaCO}_{3} \text { Consumption }}{\frac{\text { Grams/Liter of }}{\text { Solution }}}$} \\
\hline & $\mathrm{Al}_{2} \frac{\mathrm{O}}{3}$ & $\mathrm{Fe}^{+t}$ & Mo & $\mathrm{A} 12 \mathrm{O} 3$ & $\mathrm{Fe}^{++}$ & Mo & \\
\hline $\begin{array}{l}3.5 \\
3.8 \\
4.1\end{array}$ & $\begin{array}{l}3.6 \\
2.6 \\
0.2\end{array}$ & $\begin{array}{l}0.13 \\
0.045 \\
0.003\end{array}$ & $\begin{array}{l}0.017 \\
0.007 \\
0.002\end{array}$ & $\begin{array}{l}10 \\
35 \\
95\end{array}$ & $\begin{array}{r}97.4 \\
99.1 \\
>99.9\end{array}$ & $\begin{array}{l}98.3 \\
99.3 \\
99.8\end{array}$ & $\begin{array}{l}22 \\
28 \\
33\end{array}$ \\
\hline
\end{tabular}

Test II Head Assay: $\mathrm{Al}_{2} \mathrm{O}_{3}, 18 \mathrm{~g} / 1 ; \mathrm{MO}, 1.0 \mathrm{~g} / 1 ; \mathrm{Fe}^{+++}, 5.0 \mathrm{~g} / \mathrm{I}$

\begin{tabular}{|c|c|c|c|c|c|c|c|}
\hline \multirow[b]{2}{*}{$\mathrm{pH}$} & \multicolumn{3}{|c|}{$\frac{\text { Filtrate Assay }}{\text { Grams/iter }}$} & \multicolumn{3}{|c|}{ \& Precipitated } & \multirow{2}{*}{$\frac{\mathrm{CaCO}_{3} \text { Consumption }}{\frac{\text { Grams/Liter of }}{\text { Solution }}}$} \\
\hline & $\mathrm{Al}_{2} \mathrm{O}_{3}$ & $\mathrm{Fe}^{t+t}$ & Mo & $\mathrm{Al}_{2} \mathrm{O}_{3}$ & $\mathrm{Fe}++t$ & Mo & \\
\hline $\begin{array}{l}3.5 \\
3.8 \\
4.1\end{array}$ & $\begin{array}{r}16.0 \\
9.6 \\
0.3\end{array}$ & $\begin{array}{l}1.84 \\
0.10 \\
0.004\end{array}$ & $\begin{array}{l}0.23 \\
0.018 \\
<0.001\end{array}$ & $\begin{array}{l}11.1 \\
46.7 \\
98.3\end{array}$ & $\begin{array}{r}62.2 \\
98.0 \\
>99.9\end{array}$ & $\begin{array}{l}77.0 \\
98.2 \\
99.9\end{array}$ & $\begin{array}{l}40 \\
58 \\
72\end{array}$ \\
\hline
\end{tabular}

Test III Head Assay: $\mathrm{Al}_{2} \mathrm{O}_{3}, 30 \mathrm{~g} / \mathrm{I} ; \mathrm{Mo}, 1.0 \mathrm{~g} / \mathrm{I} ; \mathrm{Fe}^{+++}, 5.0 \mathrm{~g} / 1$

\begin{tabular}{|c|c|c|c|c|c|c|c|}
\hline \multirow[b]{2}{*}{$\mathrm{pH}$} & \multicolumn{3}{|c|}{$\frac{\text { Filtrate }}{\text { Grams/Liter }}$} & \multicolumn{3}{|c|}{ \% Precipitated } & \multirow{2}{*}{$\frac{\mathrm{CaCO}_{3} \text { Consumption }}{\frac{\text { Grams/Liter of }}{\text { Solution }}}$} \\
\hline & $\mathrm{Al}_{2} \mathrm{O}_{3}$ & $\mathrm{Fe}^{+t}$ & Mo & $\mathrm{Al}_{2} \mathrm{O}_{3}$ & $\mathrm{Fe}^{++-}$ & Mo & \\
\hline $\begin{array}{l}3.3 \\
3.8 \\
4.1\end{array}$ & $\begin{array}{c}27.0 \\
11.5 \\
0.03\end{array}$ & $\begin{array}{l}4.29 \\
0.089 \\
0.003\end{array}$ & $\begin{array}{l}0.81 \\
0.013 \\
0.002\end{array}$ & $\begin{array}{l}10.0 \\
61.7 \\
99.9\end{array}$ & $\begin{array}{r}14.2 \\
98.2 \\
>99.9\end{array}$ & $\begin{array}{l}19 \\
98.7 \\
99.8\end{array}$ & $\begin{array}{r}87 \\
127 \\
144\end{array}$ \\
\hline
\end{tabular}


Table IX. Composition of Precipitates

Test I. Molar Ratio Mo/Fe $=4 / 1$

Analys is of Precipitate in $\%$

\begin{tabular}{ccccc}
$\mathrm{pH}$ & & Mo & Fe & \multicolumn{2}{c}{ L.O.I. at $450^{\circ} \mathrm{C}$} & & Molar Ratio Mo/Fe \\
\cline { 2 - 4 } 1.70 & 48.1 & 8.11 & 10.9 & 3.45 \\
2.05 & 47.6 & 9.25 & 10.3 & 2.99 \\
3.00 & 50.7 & 12.5 & 6.2 & 2.36 \\
3.50 & 50.6 & 13.5 & 6.9 & 2.18
\end{tabular}

Test II Molar Ratio Mo/Fe $=2 / 1$

Analysis of Precipitate in $\%$

\begin{tabular}{|c|c|c|c|c|}
\hline $\mathrm{nH}$ & $M_{0}$ & Fe & ecipluace in of & Molon Potio Mo/Fo \\
\hline & & $F$ & N.0.1. al $4: 0 \mathrm{C}$ & Molal nal 10 dMU/Fe \\
\hline $\begin{array}{l}1.75 \\
2.00 \\
3.00 \\
3.50\end{array}$ & $\begin{array}{l}45.6 \\
46.7 \\
46.9 \\
47.6\end{array}$ & $\begin{array}{l}12.0 \\
13.3 \\
15.1 \\
15.6\end{array}$ & $\begin{array}{l}8.15 \\
6.33 \\
6.22 \\
4.35\end{array}$ & $\begin{array}{l}2.21 \\
2.04 \\
1.81 \\
1.77\end{array}$ \\
\hline
\end{tabular}

Test III Molar Ratio Mo/Fe $=1 / 1$

Analysis of Precipitate in $\%$

$\mathrm{pH} \quad \mathrm{Mo}$ Fe L.O.I. at $450^{\circ} \mathrm{C}$

\begin{tabular}{|c|c|c|c|c|}
\hline & & & & $\mathrm{Fe}$ \\
\hline $\begin{array}{l}1.8 \\
2.2 \\
3.0 \\
3.5\end{array}$ & $\begin{array}{l}43.9 \\
43.3 \\
41.2 \\
38.9\end{array}$ & $\begin{array}{l}12.9 \\
15.5 \\
21.2 \\
23.2\end{array}$ & $\begin{array}{l}9.95 \\
7.04 \\
4.72 \\
6.85\end{array}$ & $\begin{array}{l}1.98 \\
1.62 \\
1.13 \\
0.98\end{array}$ \\
\hline
\end{tabular}


Coprecipitation of Uranium During Precipitation of Iron and Molybdenum

Test I. U308, $1.0 \mathrm{~g} / 1 ; \mathrm{MO}, 1.0 \mathrm{~g} / 1 ; \mathrm{Fe}^{+++}, 1.5 \mathrm{~g} / 1$

Filtrate Assay.

\begin{tabular}{l}
$\mathrm{pH}$ \\
\hline 2.8 \\
3.2 \\
3.6
\end{tabular}

\begin{tabular}{c}
$\mathrm{pH}$ \\
\hline 2.8 \\
3.2 \\
3.6
\end{tabular}
Grams/Liter

U308 $\mathrm{Fe}^{+++} \mathrm{MO}$

$\begin{array}{lll}0.99 & 1.21 & 0.36\end{array}$

$\begin{array}{llll}0.97 & 0.163 & 0.048\end{array}$

$0.940 .008 \quad 0.003$

\section{Filtrate Assay}

\section{Grams/Liter.}

U30 $\overline{\mathrm{Fe}+++} \mathrm{Mo}$

$\begin{array}{lll}0.99 & 1.42 & 0.18\end{array}$

$\begin{array}{llll}0.94 & 0.046 & 0.006\end{array}$

$\begin{array}{llll}0.85 & 0.007 & 0.001\end{array}$
Precipitate

$\mathrm{U}_{308 \%}$ Wt. (g) $\% \mathrm{U}_{3} \mathrm{O}_{8}$ Precipitated

$0.26 \quad 1.0$

$0.16 \quad 8.9$

0.33

8.9

0.52

2.83

5.88

Test II $\mathrm{U}_{3} 0 \mathrm{~g}, 1.0 \mathrm{~g} / \mathrm{I} ; \mathrm{MO}, 1.0 \mathrm{~g} / 1 ; \mathrm{Fe}^{+++}, 5.0 \mathrm{~g} / 1$

Precipitate

U308\% Wt $(\mathrm{g}) \%$ U308 Precipitated

$0.057 \quad 4.4$

$0.30 \quad 10.0$

0.6510 .6
0.5

6.0

13.8

Test III U30g, $1.0 \mathrm{~g} / 1 ; \mathrm{MO}, 1.0 \mathrm{~g} / 1 ; \mathrm{Fe}^{+++}, 10.0 \mathrm{~g} / 1$

Filtrate Assay Grams/Liter

$\mathrm{pH} \quad \mathrm{U}_{3} \mathrm{O}_{8} \mathrm{Fe}^{+++} \mathrm{MO}$

2.8

3.2

3.6 $\begin{array}{llll}0.95 & 0.50 & 0.050\end{array}$

0.86

0.82

0.025

0.0050 .001
Precipitate

U308\% Wt $(\mathrm{g})$ \% $\mathrm{U}_{3} \mathrm{O}_{8}$ Precipitated

$0.07 \cdot 28.0$

$0.20 \quad 30.8$

$0.27 \quad 31.8$
3.92

12.3

17.2 
Table XIII. Recovery of Uranium from Iron-Molybdenum Precipitates By An Acid Repulp

Head Solution Assay: $\mathrm{U}_{3} \mathrm{O}_{8}, 1.0 \mathrm{~g} / 1 ; \mathrm{Mo}, 1.0 \mathrm{~g} / 1 ; \mathrm{Fe}^{+++}, 5.0 \mathrm{~g} / 1$

Precipitation

$\frac{\text { Filtrate Assay }}{\text { Grams/Iiter }}$

$\mathrm{T}^{\circ} \mathrm{C} \quad \mathrm{pH} \quad \mathrm{U}_{3} \overline{\mathrm{O}_{8}} \cdot \mathrm{\textrm {Fe } ^ { + + + }}$

A $\quad 3.5 \quad 0.82 \quad 0.025 \cdot 0.003$

A $\quad 3.6 \quad 0.82 \quad 0.010 \quad 0.002$

$\begin{array}{lllll}\text { A } & 3.6 & 0.78 & 0.009 & 0.002\end{array}$

$\begin{array}{lllll}\text { A } & 3.6 & 0.77 & 0.006 & 0.001\end{array}$

$\begin{array}{llllll}\text { A } & 3.6 & 0.82 & 0.012 & 0.002 & 100\end{array}$

$\begin{array}{llllll}\text { A } & 3.6 & 0.83 & 0.004 & 0.001 & 100\end{array}$

$\begin{array}{llllll}\text { A } & 3.6 & 0.81 & 0.008 & 0.001 & 100\end{array}$

$\begin{array}{llllll}\text { A } & 3.6 & 0.80 & 0.008 & 0.001 & 100\end{array}$

100

2.6

0.98

$0.020 \quad 0.002$

100

2.6

0.99

0.0150 .002

$\begin{array}{llll}2.7 & 0.97 & 0.008 & 0.001\end{array}$

100

100

100

100

100

100

100
Repulp

Filtrate Assay

Grams/i-iter

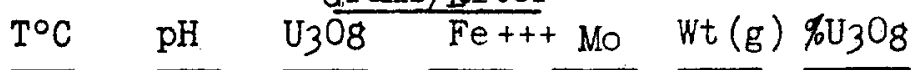

$$
\text { A } \quad 3.0
$$

0.16

0.047

0.003

$13.0 \quad 0.047$

$0.17 \quad 0.54$

$\begin{array}{lll}0.036 & 12.4 & 0.010\end{array}$

$0.22 \quad 4.05 \quad 0.62$

$8.6 \quad 0.0013$

0.98

$8.0 \quad 0.0010$

$0.24 \quad 4.95$

2.3

0.19

0.039

0.002

$12.2 \quad 0.007$

0.17

0.38

0.00

11.

0.006

$0.19 \quad 2.12$

0.07

10.6

$0.20 \quad 4.95$

0.99

$\begin{array}{ll}5.6 & 0.001\end{array}$

$\begin{array}{lllll}0.025 & 0.009 & 0.001 & 13.8 & 0.040\end{array}$

3.0

2.5

0.0060 .070

0.00

13.

0.020

2.0

0.0300 .370

0.00

12.60 .020

1.5

0.0251 .64

0.14

12.

1.0

$0.0154 .34 \quad 0.86$

8.10 .012

$\begin{array}{lllllll}2.3 & 0.022 & 0.014 & 0.001 & 13.6 & 0.007\end{array}$

$\begin{array}{lllllll}2.0 & 0.010 & 0.259 & 0.004 & 12.6 & 0.0038\end{array}$

8.50 .0041

5.80 .0029
$\% \mathrm{U}_{3} \mathrm{O}_{8}$

of Head

1.2

0.25

0.02

0.02

0.17

0.14

0.11

0.01

1.1

0.53

0.50

0.48

0.19

0.19

0.10

0.08

0.03 
Table XIV

Precinitation of Molybdenum from Ambros 1a Lake District Ores

Sample 331-1

\begin{tabular}{|c|c|c|c|c|c|c|c|c|c|c|c|c|c|c|c|c|c|c|c|}
\hline \multirow{3}{*}{$\begin{array}{l}\text { Test } \\
\text { Numcer }\end{array}$} & \multirow{2}{*}{\multicolumn{2}{|c|}{$\begin{array}{l}\text { Leaching } 1 / \\
\text { Conditions } \\
\text { Lb/Ton }\end{array}$}} & \multirow{2}{*}{\multicolumn{2}{|c|}{$\begin{array}{l}\text { Terminal } \\
\text { Conditions }\end{array}$}} & \multirow{2}{*}{\multicolumn{2}{|c|}{$\begin{array}{l}\text { Terminal } \\
\text { Conditions }\end{array}$}} & \multirow{3}{*}{$\begin{array}{l}\text { Residue } \\
\text { Asssay } \\
\mathrm{U}_{3} \mathrm{O}_{8}\end{array}$} & \multirow{3}{*}{$\begin{array}{l}\mathrm{W}_{3} \mathrm{O}_{8} \\
\text { Ext'n }\end{array}$} & \multicolumn{5}{|c|}{ Liquor Before $\mathrm{CaCO}_{3}$} & \multicolumn{6}{|c|}{ Liquor after $\mathrm{CaCO}_{3}$} \\
\hline & & & & & & & & & & & Grams & ter & & & & Gramg/ & ter & & $\mathrm{CaCO}_{3}$ \\
\hline & $\mathrm{H}_{2} \mathrm{SO}_{4}$ & $\mathrm{MnO}_{2}$ & $\mathrm{pH}$ & $\overline{E m} r(m \div)$ & $\mathrm{pH}$ & $\overline{E m f(m v)}$ & & & $\mathrm{pH}$ & $\overline{V_{3} 0_{8}}$ & Mo & $\mathrm{Fe}^{\prime}$ & $\mathrm{So}_{4}$ & $\underline{p H}^{H}$ & $\mathrm{U}_{3} \mathrm{O}_{8}$ & Mo & Fe & $\mathrm{SO}_{4}$ & Lb/TOD \\
\hline 1 & 165 & 20 & 1.7 & - & - & - & 0.010 & 93.6 & 1.8 & 0.37 & 0.047 & 0.42 & - & 3.7 & 0.34 & 0.002 & 0.035 & 6.13 & 40 \\
\hline 2 & 155 & 20 & 1.9 & - & 2.2 & - & 0.012 & 91.8 & 2.6 & 0.38 & 0.078 & 0.76 & 6.60 & 3.9 & 0.35 & $<0.001$ & 0.019 & 4.21 & 22 \\
\hline 3 & 175 & 10 & 1.4 & - & 1.9 & - & 0.013 & 91.4 & 2.2 & 0.41 & 0.053 & 1.47 & 7.80 & 3.6 & 0.39 & 0.001 & 0.033 & 3.10 & 22 \\
\hline 4 & 175 & 10 & 1.3 & -595 & 2.2 & -550 & 0.013 & 91.4 & 2.3 & 0.38 & 0.056 & 1.19 & 8.40 & 3.6 & 0.38 & $<0.001$ & 0.046 & 4.72 & 22 \\
\hline 5 & 175 & 10 & 1.3 & -535 & 2.3 & -500 & 0.012 & 91.9 & 2.4 & 0.38 & 0.038 & 1.52 & 8.42 & 3.6 & 0.36 & $<0.001$ & 0.057 & 6.90 & 21 \\
\hline 6 & 175 & 10 & 1.1 & -520 & 1.9 & -500 & 0.006 & 96.0 & 2.1 & 0.41 & 0.070 & 1.87 & 9.52 & 3.6 & 0.38 & 0.001 & 0.105 & 4.78 & 27 \\
\hline 7 & 175 & 10 & 1.1 & -520 & 2.0 & -490 & 0.009 & 94.0 & 2.3 & 0.44 & 0.083 & 2.13 & 9.05 & 3.5 & 0.40 & 0.002 & 0.170 & 4.95 & 28 \\
\hline
\end{tabular}

1/ Five hundred grams of minus 10 -mesh ore were ground for 10 minutes at 67 per cent sol1ds, then leached at 50 per cont solids for 4 hours at ambient temperature.

2) Terminal conditions of acid leach.

3/ Terminal conditions after repulping the neutralieation precipitate in acid leach pulp for 30 aibutes. 


$$
34
$$

\section{Table XV}

Precipltation of Molybdenum from Lignite Leach Liquors by Neutralization with Calcium Carbonate

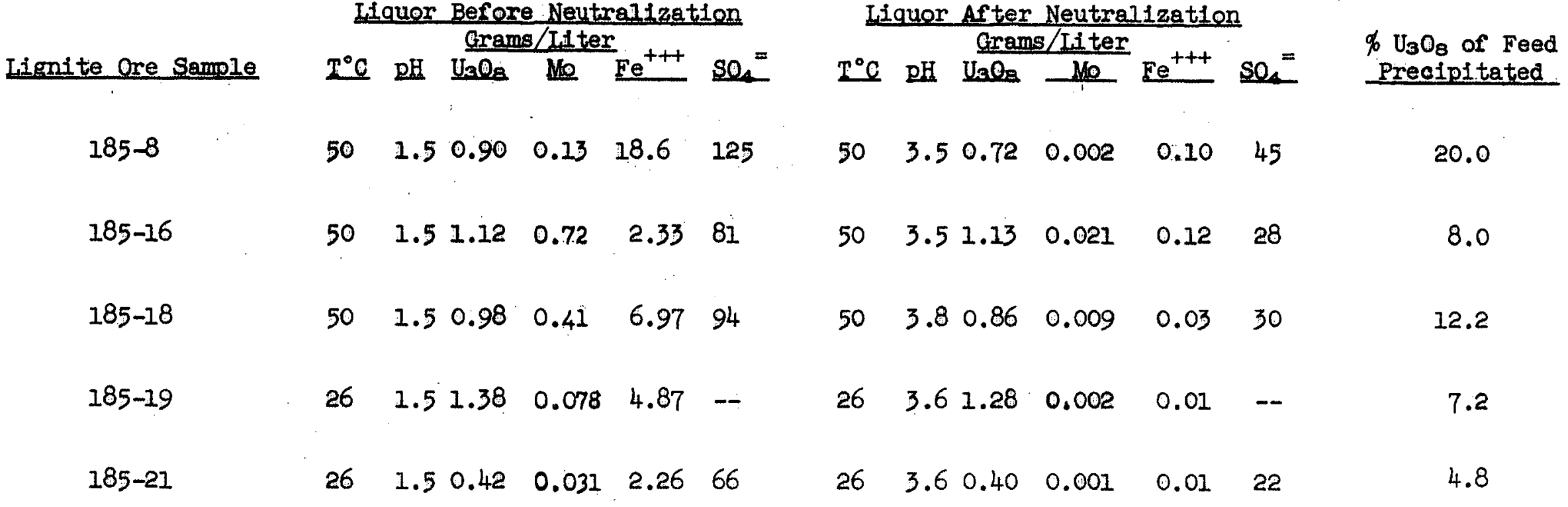


Table XVIII

Effect of Recycling Repulp Filtrate (185-16 Leach Liquor)

Precipitation of Molybdenum with $\mathrm{CaCO}_{3}$ at $50^{\circ} \mathrm{C}$

\begin{tabular}{|c|c|c|c|c|c|c|c|c|c|c|c|c|c|c|c|}
\hline \multirow[t]{3}{*}{ Test No. } & \multicolumn{7}{|c|}{ L1quor Before $\mathrm{CaCO}_{3}$} & \multicolumn{7}{|c|}{ Liquor After $\mathrm{CaCO}_{3}$} & \multirow{3}{*}{$\begin{array}{c}\mathrm{CaCO}_{3} \\
\text { 1b/ton ash }\end{array}$} \\
\hline & \multirow[b]{2}{*}{$\operatorname{Vol}(1)$} & \multirow[b]{2}{*}{$\mathrm{pH}$} & \multicolumn{5}{|c|}{ Grans/Liter } & \multirow[b]{2}{*}{$\operatorname{vol}(1)$} & \multirow[b]{2}{*}{$\mathrm{pH}$} & \multicolumn{5}{|c|}{ Grams/Liter } & \\
\hline & & & $\mathrm{O}_{3} \mathrm{O}_{8}$ & Mo. & $\mathrm{Fe}^{+++}$ & $\mathrm{SO}_{4}=$ & $\mathrm{Al}_{2} \mathrm{O}_{3}$ & & & $\mathrm{U}_{3} \mathrm{O}_{8}$ & Mo & $\mathrm{Fe}^{++t}$ & $\mathrm{SO}_{4}=$ & $\mathrm{Al}_{2} \mathrm{O}_{3}$ & \\
\hline 1 & 2.00 & 1.5 & 1.57 & 0.82 & 3.42 & 102 & 19.5 & 2.90 & 3.8 & 1.00 & 0.05 & 0.03 & 27.4 & 7.6 & 380 \\
\hline 2 & 4.15 & 1.5 & 1.69 & 0.90 & 4.82 & 116 & 28.7 & 5.28 & 3.8 & 1.17 & 0.024 & 0.01 & 20.3 & 6.7 & 500 \\
\hline 3 & 3.75 & 1.9 & 1.84 & 0.65 & 2.16 & 136 & 42.2 & 4.50 & 3.5 & 1.32 & 0.124 & 0.08 & 28.6 & 7.8 & 500 \\
\hline 41 & 4.25 & 2.1 & 1.71 & 0.61 & 2.87 & 116 & 53.0 & 5.60 & 3.3 & 1.16 & 0.049 & 0.01 & 20.0 & 8.2 & 650 \\
\hline
\end{tabular}

Repule of the Precipitate

Ion Exchange




Table XIX. Effect of Leaching Temperature on $185-19$ Roasted Ore

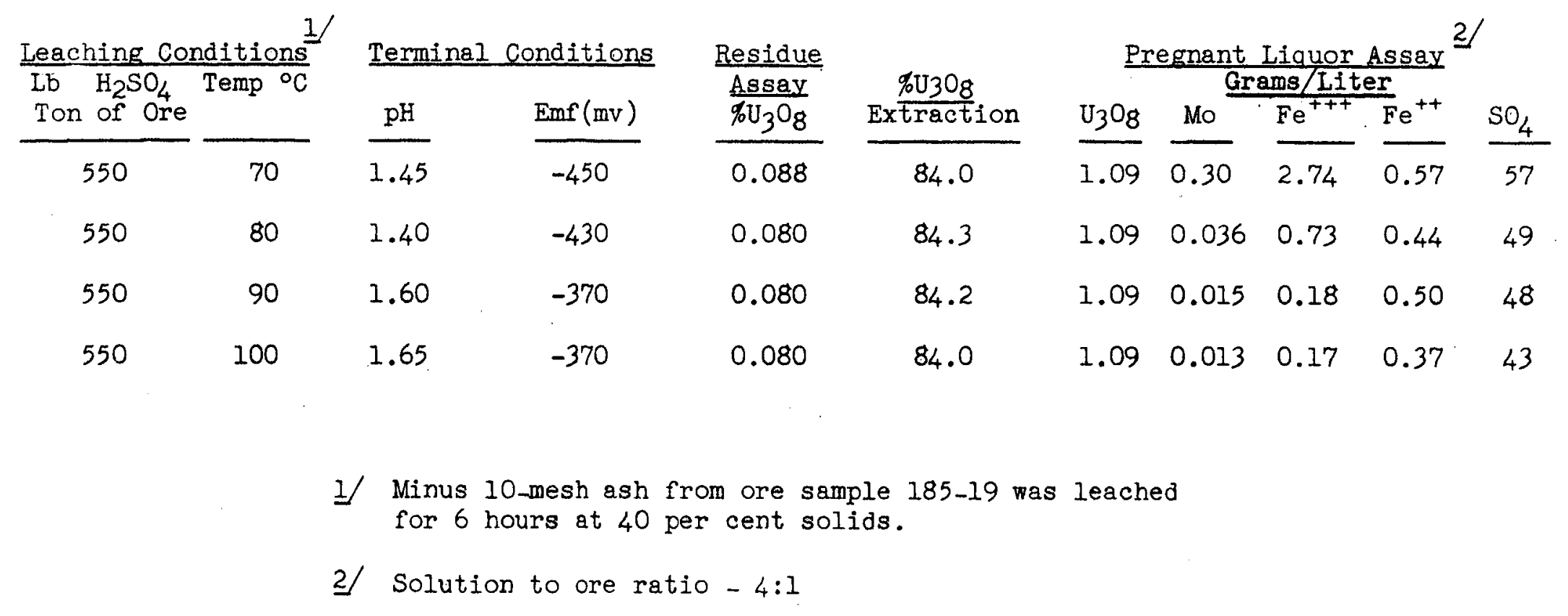


Table $\mathrm{XX}_{*} \quad$ Effect of Leaching $\mathrm{pH}$ on 185-19 Roasted Ore

\begin{tabular}{|c|c|c|c|c|c|c|c|c|}
\hline \multirow{2}{*}{$\begin{array}{c}\text { Leaching } \\
\text { Conditions } \\
\text { Lb/Ton Ash } \\
\mathrm{H}_{2} \mathrm{SO}_{4}\end{array}$} & \multicolumn{2}{|c|}{$\begin{array}{c}\text { Terminal } \\
\text { Conditions }\end{array}$} & \multirow{2}{*}{$\begin{array}{l}\text { Residue } \\
\text { Assay } \\
\% \mathrm{U}_{3} \mathrm{O}_{8}\end{array}$} & \multirow{2}{*}{$\begin{array}{l}\% \mathrm{U}_{3} \mathrm{O}_{8} \\
\text { Ext'n }\end{array}$} & \multicolumn{4}{|c|}{$\begin{array}{c}\text { Pregnant Liquor Assay } 2 / \\
\text { Grams/Liter }\end{array}$} \\
\hline & $\mathrm{pH}$ & $\operatorname{Emf}(m v)$ & & & $\overline{\mathrm{U}_{3} \mathrm{O}_{8}}$ & Mo & $\mathrm{Fe}^{++F}$ & $\overline{F e+t}$ \\
\hline 600 & 2.55 & -365 & 0.071 & 86.9 & 1.24 & 0.008 & 0.06 & 0.35 \\
\hline 700 & 2.00 & -400 & 0.064 & 88.7 & 1.27 & 0.020 & 0.063 & 0.56 \\
\hline 800 & 1.40 & -430 & 0.046 & 92.1 & 1.33 & 0.036 & 1.63 & 0.63 \\
\hline 900 & 1.10 & -445 & 0.041 & 93.1 & 1.38 & 0.069 & 4.16 & 0.71 \\
\hline 1000 & 0.70 & -470 & 0.041 & 93.1 & 1.38 & 0.114 & 5.39 & 0.81 \\
\hline
\end{tabular}

1) Minus 10 -mesh ash leached at $98^{\circ} \mathrm{C}$ and 40 per cent solids for 6 hours.".

2) At a $4: 1$ solution to ore ratio.

Note: Head assay $\mathrm{U}_{3} \mathrm{O}_{8}=0.58 \%$

Table XXI E Efect of Leaobing pH on 185,21 Roasted Ore

\begin{tabular}{|c|c|c|c|c|c|c|c|c|}
\hline \multirow{2}{*}{$\begin{array}{c}\text { Leacning } \\
\text { Conditions } \\
\text { Ib/Ton Ash } \\
\mathrm{H}_{2} \mathrm{SO}_{4}\end{array}$} & \multicolumn{2}{|c|}{$\begin{array}{c}\text { Terminal } \\
\text { Conditions } \\
\end{array}$} & \multirow{2}{*}{$\begin{array}{c}\text { Residue } \\
\text { Assay } \\
\% \mathrm{U}_{3} \mathrm{O}_{8}\end{array}$} & \multirow{2}{*}{$\begin{array}{l}\% \mathrm{U}_{3} \mathrm{Og} \\
\text { Ext'n }\end{array}$} & \multicolumn{3}{|c|}{$\begin{array}{c}\text { Pregnant Liquor } \\
\text { Grams/Liter }\end{array}$} & say \\
\hline & $\mathrm{pH}$ & $\operatorname{Emf}(\mathrm{mv})$ & & & $\mathrm{U}_{3} \mathrm{O}_{8}$ & Mo & $\mathrm{Fe}$ & $\mathrm{Fe}^{+}$ \\
\hline $\begin{array}{l}170 \\
275 \\
500 \\
600 \\
700 \\
800\end{array}$ & $\begin{array}{l}2.00 \\
1.55 \\
1.05 \\
0.70 \\
0.40 \\
0.20\end{array}$ & $\begin{array}{l}-375 \\
-400 \\
-450 \\
-465 \\
-485 \\
-510\end{array}$ & $\begin{array}{l}0.057 \\
0.040 \\
0.020 \\
0.017 \\
0.014 \\
0.013\end{array}$ & $\begin{array}{l}66.0 \\
79.2 \\
90.0 \\
91.7 \\
93.3 \\
93.9\end{array}$ & $\begin{array}{l}0.34 \\
0.36 \\
0.43 \\
0.43 \\
0.44 \\
0.44\end{array}$ & $\begin{array}{l}0.001 \\
0.003 \\
0.032 \\
0.065 \\
0.094 \\
0.173\end{array}$ & $\begin{array}{c}0.00 \\
0.10 \\
2.26 \\
4.71 \\
6.07 \\
10.5\end{array}$ & $\begin{array}{l}0.27 \\
0.48 \\
0.54 \\
0.47 \\
0.48 \\
0.56\end{array}$ \\
\hline
\end{tabular}

1) Minus 10 -mesh ash leached at $98^{\circ} \mathrm{C}$ and 40 per cent solids for 6 hours.

2) At a 4:1 solution to ore ratio.

Note: Head Assay $\mathrm{U}_{3} \mathrm{O}_{8}=0.19 \%$ 
WIN -48

$-38-$

Table XXII. Effect of Leaching pH on 185-25 Roasted Ore

Leaching $1 /$

Corditions

Lb. Ton Ash

$\mathrm{H}_{2} \mathrm{SO}_{4}$

600

670

800

1000

1200

\begin{tabular}{ll}
\multicolumn{2}{c}{$\begin{array}{c}\text { Terminal } \\
\text { Conditions }\end{array}$} \\
\hline $\mathrm{pH}$ & Emf(mv) \\
\hline 2.65 & -375 \\
2.30 & -440 \\
1.55 & -470 \\
0.90 & -515 \\
0.40 & -530
\end{tabular}

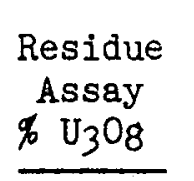

0.064

0.050

0.040

0.032

0.032

\begin{tabular}{|c|c|c|c|c|}
\hline \multirow{2}{*}{$\begin{array}{l}\% \mathrm{U}_{3} \mathrm{O}_{8} \\
\text { Ext'n }\end{array}$} & \multicolumn{4}{|c|}{$\begin{array}{l}\text { Pregnant Iiquor Assay } 2 / \\
\text { Grams/Liter }\end{array}$} \\
\hline & $\mathrm{U}_{3} \mathrm{O}_{8}$ & Mo & $\mathrm{Fe}^{++t}$ & $\mathrm{Fe}^{+f}$ \\
\hline 89.8 & 1.56 & 0.006 & 0.04 & 0.33 \\
\hline 93.0 & 1.60 & 0.031 & 0.84 & 0.36 \\
\hline 94.0 & 1.62 & 0.140 & 3.77 & 0.37 \\
\hline 95.3 & 1.65 & 0.630 & 13.4 & 0.41 \\
\hline 95.7 & 1.65 & 1.17 & 18.0 & 0.46 \\
\hline
\end{tabular}

1) Minus 10-mesh ash leached at $98^{\circ} \mathrm{C}$ and 40 per cent solids for 6 hours.

2) At a 4:1 solution to ore ratio.

Note: Head Assay $\mathrm{U}_{3} \mathrm{O}_{8}=0.69 \%$ 